Paulina Chołys, Wojciech R. Pionko

https://doi.org/10.18778/8220-636-4.07

\title{
HISTORIA MIĘDZYNARODOWEGO FESTIWALU SZTUK PRZYJEMNYCH I NIEPRZYJEMNYCH - SPISANA PRZEZ JEGO RÓWIEŚNIKÓW
}

Gdy w roku 1990 Minister Kultury i Sztuki Izabella Cywińska wprowadziła kategoryzację teatrów, istnienie Teatru Powszechnego stanęło pod znakiem zapytania. Instytucja mieszcząca się w Łodzi przy ulicy Legionów 21 otrzymała wtedy kategorię $\mathrm{C}$. Teatr był zadłużony i potrzebna była natychmiastowa reforma artystyczna. Jednym z działań podjętych w celu ratowania Powszechnego miała być organizacja festiwalu. Inicjatorami wydarzenia była ówczesna dyrekcja Teatru Powszechnego: dyrektor naczelny i artystyczny Maciej Korwin (w latach 1991-1995 $)^{1}$ i zastępca dyrektora, pomysłodawczyni wydarzenia - Ewa Pilawska, która, obejmując 13 października 1995 roku dyrekcję Teatru, rozwinęła ideę Festiwalu, została jego dyrektor artystyczną i prowadzi go do dnia dzisiejszego.

Pomysł Festiwalu pojawił się w trudnym czasie dla sceny - mówiła Pilawska - między innymi nie odbyło się kilka premier i szukaliśmy wydarzeń, które byłyby ważne z pozycji widza. Dlatego też powstał Pierwszy Ogólnopolski Permanentny Festiwal Sztuk Przyjemnych [... ], który trwał od 12 listopada 1994 roku do 22 lutego 1995 roku. Miały to być spektakle z gwiazdami bądź gwiazdą, widowiska, których obejrzenie sprawia widzowi prawdziwą przyjemność - cokolwiek to znaczy².

1 W roku 1995 Maciej Korwin objął scenę Teatru Muzycznego im. Danuty Baduszkowej w Gdyni, którą prowadził aż do swojej śmierci w roku 2013.

2 Łukasz Kaczyński, Pierwsza rocznica śmierci Macieja Korwina, inicjatora Festiwalu Sztuk Przyjemnych w Łodzi, „Dziennik Łódzki” (10 stycznia 2014), https:// dzienniklodzki.pl/pierwsza-rocznica-smierci-macieja-korwina-inicjatora-festiwalusztuk-przyjemnych-w-lodzi/ar/1085212 (dostęp: 10.04.2016). Nazwa pierwszego festiwalu brzmiała: I Ogólnopolski Permanentny Festiwal Sztuk Przyjemnych. 
Festiwal miał spowodować, iż Teatr Powszechny, nie zmieniając zasadniczo swojego profilu sceny komediowej przeznaczonej dla szerokiej grupy odbiorców, zyska nową perspektywę artystyczną, wzbogaci repertuar, zdobędzie bardziej zróżnicowane grono widzów, będzie zabiegał o ich uznanie, ale też o edukację teatralną dotychczasowej publiczności. Takie działania miały także wzmocnić nadszarpnięty prestiż Teatru i wspomóc go finansowo. I założone cele udało się osiągnąć.

Nazwa festiwalu - Ogólnopolski Permanentny Festiwal Sztuk Przyjemnych - została zainspirowana klasyfikacją Georga Bernarda Shawa, który to podzielił swoje sztuki na „przyjemne” i „nieprzyjemne”. „Sztuki przyjemne” stanowily utwory obyczajowe, żartobliwe i przystępne w odbiorze, natomiast „sztuki nieprzyjemne" to utwory programowe, odnoszące się do rzeczywistości w sposób krytyczny i nakłaniające widzów do refleksji nad „nieprzyjemnymi” aspektami życia. Zdaniem Ewy Pilawskiej określenie „przyjemne” w nazwie otwieranego festiwalu powinno się traktować nieco szerzej i łączyć przede wszystkim z poczuciem satysfakcji z „[... ] obejrzenia sztuki, która jest dobrze napisana, bardzo dobrze zrealizowana, wzbogaca widza o ważną refleksję. Poza tym bawi, uczy, także wzrusza, po prostu sprawia przyjemność” 3 .

Początki wydarzenia były jednak trudne - brakowało zewnętrznego wsparcia finansowego i merytorycznego. Festiwal powstał jako pierwsza tego typu instytucja w Łodzi na scenach dramatycznych; szukając lokalnych wzorców mógł zatem odwołać się tylko do doświadczeń operowo-baletowego Teatru Wielkiego lub - zawsze silnego w mieście - teatralnego ruchu offowego czy amatorskiego, te jednak miały swoją oczywistą specyfikę.

Inicjatorzy przeglądu od początku jego istnienia jako sprawę najistotniejszą deklarowali podjęcie dialogu $\mathrm{z}$ widzem, aranżację w Powszechnym teatralnego spotkania w szerokim gronie odbiorców. W związku z takim założeniem Festiwal miał stać się nie tyle konkursową rywalizacją, ile celebrowanym we wspólnocie artystów i widzów świętem sztuki teatru. Dlatego też zdecydowano, iż festiwalowych nagród nie będzie przyznawać jury złożone ze specjalistów, lecz sama publiczność, i to wyniki głosowania w Plebiscycie Publiczności zdecydują o ostatecznym werdykcie, to znaczy o wyłonieniu: Najprzyjemniejszej Aktorki, Najprzyjemniejszego Aktora i Najprzyjemniejszego Spektaklu Festiwalu. Materialną pamiątką uzyskanego tytułu były przez lata grafiki Anny Szyłło. Swoje osobne nagrody mogła przyznawać także - zgodnie z własnymi zasadami - Loża Przyjaciół

3 Ewa Pilawska, rozmowa z Anną Płażewską, „Gazeta Wyborcza - Łódź”, cyt. za: Archiwum cyfrowe Teatru Powszechnego w Łodzi, https://powszechny.pl/pl/5ogolnopolski-festiwal-sztuk-przyjemnych-1999-r/ (dostęp: 10.02.2016). 
Teatru Powszechnego składająca się przede wszystkim z grona sponsorów wspierających Teatr.

Energia i entuzjazm organizatorów spowodowały, że - pomimo kłopotów - na 1. Festiwal do Łodzi przyjechało aż dziewięć spektakli, i to ze znakomitą obsadą. Pierwsza edycja rozpoczęła się w listopadzie 1994 roku i trwała do lutego 1995 roku. Podczas czterech festiwalowych miesięcy zaprezentowano m.in. sztuki klasyków komediopisarstwa: Teatr Powszechny im. Zygmunta Hübnera w Warszawie przywiózł Męża i żonę Aleksandra Fredry (reż. Krzysztof Zaleski), a Teatr Ludowy w Nowej Hucie Mieszczanina szlachcicem Molière’a (reż. Jerzy Stuhr). Pokazano także niezwykle zabawną, pastiszową Piękna Lucyndę Mariana Hemara z Teatru Nowego w Poznaniu (reż. Eugeniusz Korin) oraz Czego nie widać Michaela Frayna (reż. Maciej Englert) z warszawskiego Teatru Współczesnego ${ }^{4}$. Zgodnie z wynikami Plebiscytu Publiczności na pierwszym Festiwalu nagrody dla Najprzyjemniejszych Aktorek przyznano: Marcie Lipińskiej (Dotty Otley w sztuce Frayna), Danieli Popławskiej (za rolę Ciotki Utciszewskiej w Pięknej Lucyndzie) i Joannie Żółkowskiej (Justysia w dramacie Fredry), zaś Najprzyjemniejszymi Aktorami zostali: Jerzy Stuhr (Pan Jourdain) oraz Piotr Machalica (Alfred w Mężu i żonie) 5 . Tytuł Najprzyjemniejszego Spektaklu przypadł Pięknej Lucyndzie.

Już w czasie pierwszej edycji na łódzkiej scenie można było zobaczyć plejadę aktorskich gwiazd. Obok wymienionych laureatów nagród, byli to m.in.: Krystyna Janda, Elżbieta Kępińska, Krystyna Tkacz, Janusz Gajos, Gustaw Lutkiewicz, Bronisław Pawlik, Kazimierz Kaczor, Krzysztof Kowalewski, Krzysztof Wakuliński, Wiktor Zborowski. Takie grono artystek i artystów uzmysławia jeden z celów Festiwalu - prezentowanie łódzkim widzom znakomitości polskiego teatru i filmu, a coraz częściej także - telewizji. Z niewielu materiałów, jakie zachowały się z tamtego czasu można wyczytać, iż publiczność entuzjastycznie przyjęła Festiwal, dzięki czemu znalazł on stałe miejsce na mapie kulturalnej Łodzi.

$\mathrm{Na}$ 2. Festiwal widzowie nie musieli czekać długo - zaledwie do października 1995 roku. Nowa edycja przyniosła modyfikację formuły przeglądu

4 Identyfikując prezentowane spektakle, korzystamy z programów festiwalowych oraz z Archiwum cyfrowego Teatru Powszechnego w Łodzi, zob. https://powszechny. $\mathrm{pl} / \mathrm{pl} /$ archiwum-festiwal/?strona=2 (dostęp: 20.02.2016).

5 Zob. strona Teatru Powszechnego im. Zygmunta Hübnera w Warszawie, https: / / www.powszechny.com/spektakle/maz-i-zona,s151.html?ref_page=controller,index ,action,spektakle-archiwalne,sezon,50 (dostęp: 10.03.2016); strona Teatru Nowego w Poznaniu, http://teatrnowy.pl/zespol-artystyczny/daniela-poplawska/ (dostęp: 10.03.2016); wortal Culture.pl Michał Bujnowicz, Jerzy Stuhr, czerwiec 2004, https:// culture.pl/pl/tworca/jerzy-stuhr (dostęp: 10.03.2016). 
- przedstawień było tylko pięć, więc czas imprezy skrócił się do dwóch tygodni i trudno byłoby nadal nazywać go „permanentnym”. Zadbano jednak o retusz tytułu wydarzenia, który brzmiał teraz: Ogólnopolski Festiwal Sztuk Przyjemnych. Wśród oferty repertuarowej pojawiła się także premiera specjalnie przygotowana przez gospodarzy, co stało się odtąd praktykowanym w Powszechnym corocznym festiwalowym obyczajem. Pierwszym takim przedstawieniem była polska prapremiera popularnej w całej Europie farsy Michaela Cooney'a Cash on Delivery - w polskiej wersji: $Z$ raczzki do raczki - zrealizowana przez Marcina Sławińskiego, reżysera i aktora, od 1995 roku związanego z łódzką sceną i z samym Festiwalem. W czasie 2. Festiwalu widzowie mogli obejrzeć również spektakle: Mój przyjaciel Harvey Mary Chase (także w reżyserii Sławińskiego, ale tym razem spektakl został przygotowany z zespołem warszawskiego Teatru Kwadrat), Ambasadora Sławomira Mrożka z Teatru Współczesnego (w mistrzowskiej reżyserii Erwina Axera i z popisowymi rolami Zbigniewa Zapasiewicza, Mai Komorowskiej, Krzysztofa Kowalewskiego, Henryka Bisty i Marcina Trońskiego) oraz 33 omdlenia do tekstów Antona Czechowa (reż. Zapasiewicz, Teatr STU, Kraków), które to przedstawienie otrzymało Tytul Najprzyjemniejszego Spektaklu. Domykała przegląd sztuka Woody'ego Allena, Zagraj to jeszcze raz, Sam (reż. Korin, Teatr Nowy w Poznaniu). Najprzyjemniejszymi Aktorkami zostały: Irena Kwiatkowska (za rolę Vety Simmons w dramacie Chase) oraz Olga Sawicka (za trzy role: Smirnowej, Łomowej i Natalii w przedstawieniu Czechowowskim), zaś Tytułem Najprzyjemniejszego Aktora podzielili się: Jan Kobuszewski (za rolę Elwooda P. Dowda także w sztuce Chase) i Mirosław Kropielnicki (za rolę Allana Felixa w sztuce Allena).

Kolejny, 3. Festiwal odbył się dopiero po dwóch latach, w roku 1997. Później przegląd organizowany był corocznie - już bez żadnych przerw. Począwszy od trzeciej odsłony, Sztuki Przyjemne zyskiwały też dość precyzyjnie ustalone miejsce w teatralnym kalendarzu. Festiwal odbywał się najczęściej na przełomie stycznia i lutego, później przesunął się nieznacznie - na przełom lutego i marca, a także sporadycznie - na początek kwietnia. Tym samym na lata został wdrożony charakterystyczny rytm życia łódzkich teatromanów, podzielony na okresy: przed (do stycznia każdego nowego roku) i po (ok. marca) Festiwalu w Powszechnym, $\mathrm{z}$ emocjonującą przedakcją $\mathrm{w}$ postaci zdobywania biletów na przedstawienia. Zmiany dotknęly również tryb przyznawania przez publiczność nagrody aktorskiej. Tym razem typowano tylko po jednej nagrodzie w każdej z kategorii. I tak już pozostało, choć nie zawsze widzowie bywali konsekwentni w swojej powściągliwości przy wskazywaniu Najprzyjemniejszych Aktorek i Aktorów.

$\mathrm{Na}$ 3. Festiwalu Teatr przy ul. Legionów gościł cztery spektakle, a sam dołożył do programu piąte przedstawienie - kolejną prapremierę klasycznej farsy, przygotowaną przez Marcina Sławińskiego: O co biega? Philipa Kinga. Poza 
propozycją gospodarzy pokazano m.in. słynne Parady Jana Potockiego, ale w wersji na teatr lalek (reż. Wiesław Czołpiński) - prawdziwy ewenement w dziejach łódzkiego wydarzenia. Spektakl Białostockiego Teatru Lalek rozgrywany był wprawdzie w „żywym planie”, ale z wykorzystaniem kunsztownych lalek autorstwa Rajmunda Strzeleckiego, zbudowanych zgodnie z finezyjną techniką japońskiego bunraku6 ${ }^{6}$ Gwiazdorski warszawski Teatr Powszechny, w czasie swojej trzeciej prezentacji na Festiwalu, pokazał Ożenek Nikołaja Gogola (reż. Andrzej Domalik), tradycyjnie przywożąc do Łodzi zespół aktorskich sław (m.in. Janusz Gajos, Elżbieta Kępińska, Joanna Żółkowska, Franciszek Pieczka, Katarzyna Herman oraz w roli Podkolesina - Władysław Kowalski, który otrzymał Tytuł Najprzyjemniejszego Aktora). Mnożąc przyjemności, 3. Festiwal zaproponował też przedstawienie muzyczne, hit warszawskiego Teatru Ateneum im. Stefana Jaracza - Opera Granda, autorstwa Aldony Krasuckiej i Macieja Wojtyszki (i w jego reżyserii). Publiczność doceniła talent wokalny i zmysł autoironii gwiazdy widowiska Agnieszki Fatygi, nagradzając artystkę Tytułem Najprzyjemniejszej Aktorki, a przedstawienie uznała za Najprzyjemniejszy Spektakl. Wreszcie kolejny raz zaprezentował się uczestnik wszystkich dotychczasowych Sztuk Przyjemnych, czyli Teatr Kwadrat z Warszawy, z komedią Wszystko jest względne Alana Ayckbourna (reż. ponownie - Sławiński).

Czwarta edycja to początek roku 1998. W programie Festiwalu znalazło się już sześć przedstawień, co symptomatyczne - w większości przygotowanych przez teatry i twórców znanych z poprzednich edycji przeglądu. I tak Eugeniusz Korin i poznański Teatr Nowy zaproponowali tragifarsę Maszyna do liczenia Elmera Rice'a. Teatr Ludowy w Nowej Hucie pokazał Pana Jowialskiego Aleksandra Fredry (reż. Krzysztof Orzechowski) - z nagrodzonym laurem Najprzyjemniejszego Aktora Marianem Cebulskim w roli tytułowej. Zbigniew Zapasiewiczi Olga Sawicka dali mistrzowski popis, grając Kochanego kłamcę Jerome’a Kilty'ego, spektakl o „duchowym patronie” łódzkiego festiwalu George’u Bernardzie Shaw (Teatr STU), a Andrzej Domalik i warszawski Teatr Powszechny przywieźli jeszcze jedno słynne przedstawienie: Marię Callas. Lekcjęs śpiewu Terrence’a McNally'ego ze znakomitą tytułową rolą Krystyny Jandy. 4. Festiwal przyniósł także dwie inscenizacje Agnieszki Glińskiej: Moralność Pani Dulskiej Gabrieli Zapolskiej, premierowe przedstawienie gospodarzy - z nagrodzoną laurem Najprzyjemniejszej Aktorki Barbarą Szczęśniak w roli Dulskiej, oraz cieszący się uznaniem krytyki Korowód Arthura Schnitzlera (Teatr Ateneum), który został wybrany Najprzyjemniejszym Spektaklem.

6 Zob. Liliana Bardijewska, Kto się boi lalek?, „Gazeta Wyborcza Stołeczna” 1996, nr 196, za: http://encyklopediateatru.pl/artykuly/156225/kto-sie-boi-lalek (dostęp: 10.07.2016). 
Festiwal coraz wyraźniej kształtował swój profil, zyskując opinię wydarzenia przeznaczonego dla szerokiego odbiorcy, o raczej zachowawczych gustach, spragnionego przede wszystkim kontaktu $\mathrm{z}$ artystami dobrze znanymi z mediów. Taka formuła nadawała przeglądowi charakter impresaryjny. „Publiczność czeka na głośne nazwiska - mówiła Ewa Pilawska - więc zapraszanie gwiazd stało się naszą tradycją" uważał: „[...] samo wejście Janusza Gajosa czy Jerzego Stuhra wywoływało na widowni burzę oklasków" 8 .

5. Festiwal w 1999 roku wyznaczył skromny jubileusz wydarzenia i skłaniał do jego pierwszych podsumowań. Z dzisiejszej perspektywy można dostrzec, że już sam zestaw pokazanych wówczas pięciu spektakli znamionował postępującą modyfikację formuly przeglądu. Pozornie, zarówno liczba widowisk, jak i skład zaproszonych artystów nie uległy większej zmianie, a nawet zdawały się potwierdzać specyfikę Festiwalu. W programie były dwie realizacje Korina: jako propozycja gospodarzy - prapremiera polska sztuki Królik, królik Coline Serreau, francuskiej aktorki, reżyserki i pisarki, a także przygotowana z zespołem Teatru Nowego w Poznaniu autorska propozycja reżysera pt. Crocodilia, czyli Coś Niesamowitego. Obok nich natomiast kolejna efektowna sztuka $\mathrm{z}$ warszawskiego Teatru Powszechnego: Żelazna konstrukcja Wojtyszki, w reżyserii autora. Jednak $\mathrm{w}$ czasie tej samej edycji pojawiły się dwa przedstawienia zdecydowanie odbiegające od lekkiego tonu zwyczajowych tu wypowiedzi scenicznych. I to ich zaistnienie na Festiwalu miało bezpośredni wpływ na przekształcenie jego założeń programowych. Pierwszą sztuką był Bzik tropikalny według tekstów Stanisława Ignacego Witkiewicza, czyli elektryzujący debiut reżyserski Grzegorza Jarzyny z 1997 roku (na afiszu inscenizator figurowal jako Horst D’Albertis) z nonkonformistycznego Teatru Rozmaitości w Warszawie. Drugą propozycją były Opowieści Lasku Wiedeńskiego Ödöna von Horvátha, w reżyserii Glińskiej (Teatr Ateneum w Warszawie). O Bziku ... Jarzyny pisał Piotr Gruszczyński: „Czyni absurd i groteskę udziałem każdego $\mathrm{z}$ widzów, ofiarowując mu też odrobinę prawdziwej roz-

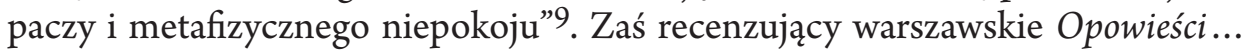

7 Ewa Pilawska, Witold Jabłoński (wywiad), „Gazeta Wyborcza - Łódź” 1998, za: Archiwum cyfrowe Teatru Powszechnego w Łodzi, https://powszechny.pl/pl/4ogolnopolski-festiwal-sztuk-przyjemnych-1998-r/ (dostęp: 10.08.2016).

8 Konrad Zieliński, I w nieprzyjemnych przyjemność, dział Dobre Miasto Łódź, „Tygiel Kultury” 2006, nr 10-12, za: wortal www.e-teatr.pl, http://www.e-teatr.pl/pl/ artykuly/35263,druk.html (dostęp: 17.08.2016).

9 Piotr Gruszczyński, „Tygodnik Powszechny” (2 marca 1997), cyt. za: Beata Zatońska, Finisaż „Bzika tropikalnego", wortal: www.e-teatr.pl, http://www.e-teatr.pl/pl/ artykuly/19878,druk.html (dostęp: 18.08.2016). 
Jarosław Komorowski, by scharakteryzować ów utwór, cytował słowa Hansa Siemsena, opisującego berlińską prapremierę dzieła von Horvátha w 1931 roku: „Ta gorzka i trudna sztuka bije po łbie, kopie w brzuch i strzela w serce tej części publiczności, która - syta - żąda łatwej zabawy w teatrze" 10 . Taka zmiana poetyki Festiwalu - prowokacyjna dla tradycjonalistycznie usposobionej publiczności - mogła przynieść poważny kryzys przebiegu wydarzenia. Dobrze rozumiejąc zagrożenie, dyrekcja Teatru postanowiła jednak kontynuować tę właśnie linię:

Dokonał się pewien zwrot. Publiczności przywykłej do ciepłych komedii i sprawnej farsy - deklarowała Ewa Pilawska - postanowiłam zaproponować trudniejsze tematy i postawić pytania o kondycje człowieka i świata. Nie chciałam - i wciąż nie chcę - aby festiwal skostniał, a do wymiany myśli niezbędna jest prezentacja przede wszystkim dobrego teatru, nawet jeśli podjęte ryzyko miało wiązać się z wymianą publiczności, gotowa byłam je podjąć ${ }^{11}$.

Pewnym wsparciem dla decyzji organizatorów mogło wydawać się rozstrzygnięcie plebiscytu publiczności i przyznanie nagród Najprzyjemniejszych: Dominice Ostałowskiej za rolę Marianny w Opowieściach ... oraz Cezaremu Kosińskiemu za rolę Sydneya Price'a w Bziku ... Jednak nagrodę dla Najprzyjemniejszego Spektaklu zdobyła, obliczona na efekt zauroczenia widza feerią zmian, Crocodilla ... 12, co wiele mówi o faktycznych upodobaniach ówczesnej publiczności, a tym samym - pilnej potrzebie rozwijania edukacyjnej misji Festiwalu.

Ostatnia edycja w XX wieku to sześć spektakli i ponownie znani łódzkim widzom artyści i teatry. Niezmiennie Korin, który tym razem przywiózł z Poznania spektakl Fredro dla dorosłych według Męża i żony Fredry. Tytułem Najprzyjemniejszego Aktora (znów jednym $\mathrm{z}$ aż trzech przyznanych w plebiscycie) został wyróżniony, grający w tym przedstawieniu rolę Hrabiego Wacława, Mariusz Sabiniewicz. Sławiński z zespołem gospodarzy zrealizował polską prapremierę głośnej sztuki Paula Pörtnera Szalone nożyczki (z pierwszym odtwórcą roli fryzjera Tonia Wziętego - Jackiem Łuczakiem, także Najprzyjemniejszym Aktorem). Sztuka do dziś ustanawia rekordy frekwencyjne na tódzkich scenach

10 Jarosław Komorowski, Dolino moja, Wachau, „Teatr” 1999, nr 2, cyt za: Encyklopedia Teatru Polskiego, http://encyklopediateatru.pl/artykuly/91938/dolinomoja-wachau (dostęp: 20.08.2016).

11 Cyt. za.: Konrad Zieliński, I w nieprzyjemnych...

12 Zob. Ewa Obrębowska-Piasecka, Coś niesamowitego?, „Gazeta Wielkopolska” 1998, nr 279, za: wortal www.hypatia.pl, http://www.hypatia.pl/web/pageFiles/ attachments/5296/gazeta-wielkopolska-nr-279-28-29-listopada-1998.pdf (dostęp: 19.08.2016). 
- od 1999 roku nie schodzi z afisza i zagrano ją już w Powszechnym znacznie ponad tysiąc razy. Spośród przedstawień z tradycyjnego nurtu repertuarowego Festiwalu pojawiła się propozycja niewidzianego jeszcze tutaj krakowskiego Teatru Bagatela - Po latach o tej samej porze Bernarda Slade'a (reż. Teresa Kotlarczyk), czyli kontynuacja słynnego utworu dramaturga: Za rok o tej samej porze. Liryczną komedię o dwojgu nietuzinkowych kochankach przedstawili w Łodzi znani aktorzy Starego Teatru: Anna Dymna (Tytuł Najprzyjemniejszej Aktorki) i Tadeusz Huk ${ }^{13}$. Temat miłości podjął też Teatr Ateneum w Cyranie do Bergerac Edmonda Rostanda (reż. Zaleski) z rewelacyjną tytułową rolą Piotra Fronczewskiego (także Najprzyjemniejszy Aktor). Legendarna kreacja Fronczewskiego zachwyciła publiczność, ale nie mniej intensywnym przeżyciem okazały się dwa przedstawienia reprezentujące nowy rodzaj festiwalowych widowisk: Kaleka $z$ Inishmaan Martina McDonagha, w reżyserii Glińskiej i Władysława Kowalskiego, oraz Magnetyzm serca według Ślubów panieńskich Fredry w inscenizacji Jarzyny (występującego tym razem pod pseudonimem - Sylwia Torsh). Oparty na autentycznych wydarzeniach dramat McDonagha to rodzaj obyczajowej „czarnej komedii”, przenikliwej w rozpoznawaniu międzyludzkich relacji. „Irlandzki dramaturg konstruuje swoje sztuki jak farsy sytuacyjne - pisał Paweł Sztarbowski - lecz wypełnia je scenami okrucieństwa i wymyślnych tortur"14. Magnetyzm serca zaś to kolejne, po Bziku tropikalnym, słynne w tym czasie przedstawienie TR Warszawa, reinterpretujące kanoniczne ujęcia klasyki teatralnej. Także tu Jarzyna „[...] tradycję teatralną związaną z tym utworem przywołał przede wszystkim, by ją dyskretnie parodiować, lecz stworzył spektakl porywający, rozedrgany emocjami, zarazem przejmujący i niebywale komiczny" 15 . Obydwa przedstawienia przemieniały sposób rozumienia teatralnej „przyjemności” obcowania ze sztukami o komediowym czy tragikomicznym statusie.

Trzeba zauważyć, że spektakle prezentowane na festiwalowej scenie Powszechnego coraz częściej reprezentowały najwybitniejsze polskie inscenizacje mijającego sezonu/ sezonów teatralnych (Bzik... nagrodzono m.in. Grand

13 [Obydwie sztuki Bernarda Slade’a Ewa Pilawska wyreżyserowała (w 2005 i 2006 r.) w założonym przez siebie przy Teatrze Powszechnym w Łodzi Teatrze dla niewidomych $i$ stabo widzących, o inicjatywie - w sposób nieoczywisty kontynuującej festiwalowe dokonania i mającej duże znaczenie w życiu teatralnym Łodzi - pisze w niniejszej książce Anna Maria Dolińska - przyp. red.]

14 Paweł Sztarbowski, Teatralny Tarantino, „Newsweek Polska” 2006, nr 46, cyt. za: wortal: www.e-teatr.pl, http://www.e-teatr.pl/pl/artykuly/31474.html (dostęp: 18.09.2016).

15 Rafał Węgrzyniak, „Magnetyzm serca” czyli „Śluby panieńskie”, „Odra” 1999, nr 10, cyt. za: Encyklopedia Teatru Polskiego, http://encyklopediateatru.pl/artykuly/159078/ magnetyzm-serca-czyli-sluby-panienskie (dostęp: 14.07.2016). 
Prix 22. Opolskich Konfrontacji Teatralnych; Magnetyzm... został uhonorowany m.in. pierwszą nagrodą na toruńskim „Kontakcie”, a Kalekę ... docenili jurorzy Kaliskich Spotkań Teatralnych), co uwidaczniało politykę repertuarową Festiwalu, który powoli stawał się tym, czym jest dziś - wyposażonym w poznawcze i edukacyjne walory przeglądem najwybitniejszych nowych polskich inscenizacji.

Wiek XXI Teatr Powszechny przywitał siódmą edycją Festiwalu i siedmioma spektaklami w jego repertuarze. W pewnym sensie symbolicznie, wobec charakteru wydarzenia, otworzył przegląd Kwartet Ronalda Harwooda z warszawskiego Teatru Współczesnego. Widowisko, wyreżyserowane, a także zagrane przez Zbigniewa Zapasiewicza - w towarzystwie Mai Komorowskiej (Najprzyjemniejszej Aktorki Festiwalu), Zofii Kucówny i Janusza Michałowskiego - stanowiło z pewnością przykład przedstawienia, w którym już sam zestaw artystów przyprawiał publiczność o silne emocje, potęgowane jeszcze wybitną kreacją Komorowskiej. Obok utworu Harwooda na 7. Festiwalu pokazano „jeden z najgłośniejszych dramatów ostatnich lat"16, czyli Sztukę Yasminy Rezy (reż. Paweł Miśkiewicz, Teatr Polski, Wrocław) - ironiczny sceniczny dyskurs na temat istoty więzi między bliskimi sobie ludźmi. Korin przywiózł z poznańskiego Teatru Nowego Cenę Arthura Millera, przedstawienie w dramatyczny sposób poruszające zagadnienie odpowiedzialności i poświęcenia. Spektakl zagrany został - jak pisano w programie - przez cały „klan Machaliców”: ojca Henryka (co symptomatyczne dla zdominowanej przez media kultury, reklamowanego jako gwiazda serialu Z Zotopolscy...) oraz synów Piotra i Aleksandra ${ }^{17}$. Pomimo takich medialno-marketingowych serwitutów prezentowane na 7. Festiwalu klasyczne komedie dalekie były od farsowej beztroski. Świetna Szkoła żon Molière’a z Teatru Narodowego, wyrafinowana także muzycznie dzięki kompozycjom Macieja Małeckiego (wykonywanym na scenie przez akompaniujących sobie na instrumentach aktorów!), wyreżyserowana została przez Jana Englerta, kreującego też rolę Arnolfa. Zarówno Englert, jak i spektakl zyskali Tytuły Najprzyjemniejszych. Ta pierwsza wizyta na Festiwalu najważniejszej polskiej sceny, z którą przyjechał także jej ówczesny dyrektor artystyczny - Jerzy Grzegorzewski, niewątpliwie nobilitowała łódzki przegląd. Kolejna z przedstawionych w tej edycji komedii Molière’a - Skqpiec z Ateneum (reż. Zaleski) także nie należała do beztrosko żartobliwych, ludycznych utworów. Nawet Wesołe kumoszki z Windsoru Williama Shakespeare'a, zrealizowane przez Piotra Cieplaka (Teatr Powszechny, Warszawa), nie były tylko zabawne. Taką kwalifikację mogła zyskać przygotowana przez gospodarzy „farsa fars” - Czego nie widać (Noises Off) Michaela Frayna w reżyserii Korina, ale w wypadku tej autotematycznej sztuki samo śledzenie spiętrzania się komicznych

16 VII Ogólnopolski Festiwal Sztuk Przyjemnych, s. 1 [program - ulotka].

17 Ibidem, s. 2. 
sytuacji jest już zadaniem atrakcyjnym poznawczo. Sposób przedstawienia perypetii bohaterów festiwalowych sztuk dałoby się podsumować formułą pożyczoną z recenzji Wesolych kumoszek... Jacka Sieradzkiego: „Można się z nich śmiać, można im współczuć. Można ich polubić”18.

W pierwszym okresie istnienia Festiwalu w skład jego repertuaru wchodziły przede wszystkim efektowne teatralnie komedie, co nawiązywało do - zsyntetyzowanej w haśle „Teatr blisko ludzi” - zasadzie programowej łódzkiego Teatru Powszechnego ${ }^{19}$. Jak podkreślaliśmy, nie rezygnowano jednak także ze spektakli poważniejszych, gatunkowo i estetycznie niejednorodnych. W ofercie festiwalowej z roku na rok było takich sztuk coraz więcej. W siódmej edycji Festiwalu już zdecydowaną większość zaproszonych przedstawień stanowiły sztuki, w których przeważała ironia i szyderstwo, a błyskotliwe, cięte i gorzkie dialogi zastępowały żartobliwą farsową konwersację.

W czasie 8 . Festiwalu już nieomal wszystkie sztuki stanowiły prawdziwe wyzwanie dla widza, bowiem prowokując śmiech, pobudzały jednocześnie jego wielki potencjał krytyczny. Rzut oka na zestaw przedstawień uświadamia sens dokonującej się transformacji: Nad Złotym Stawem Ernesta Thompsona (reż. Zapasiewicz i z nim w roli profesora Thayera, za którą otrzymał Tytuł Najprzyjemniejszego Aktora, Teatr Powszechny w Warszawie); dwie sztuki Witolda Gombrowicza - premierowa Ferdydurke gospodarzy (reż. Waldemar Śmigasiewicz) oraz Operetka (reż. Jacek Bunsch, Teatr Zagłębia w Sosnowcu); kolejna już na Festiwalu - Moralność pani Dulskiej Zapolskiej (reż. Anna Augustynowicz, Teatr Współczesny w Szczecinie); Kolacja dla głupca Francisa Vebera (reż. Wojciech Adamczyk, Teatr Ateneum; za rolę Pignona w tym przedstawieniu Tytuł Najprzyjemniejszego Aktora otrzymał - ex aequo z Zapasiewiczem - Krzysztof Tyniec); a także kameralny, psychologiczny Odwrót Williama Nicholsona (wybrany Najprzyjemniejszym Spektaklem, a kreująca rolę Alicji Marta Lipińska - Najprzyjemniejszą Aktorką, reż. Maciej Englert, Teatr Współczesny). Na finał, jako Gość Specjalny Festiwalu (taki właśnie nowy rodzaj wydarzenia wprowadzono do przeglądu widowisk), ponownie wystąpił Teatr Narodowy ze spektaklem Dożywocie Fredry, w reżyserii Jana Englerta, i z nim w roli Łatki.

Sztuki zdecydowanie „przyjemne” oczywiście nadal były grane w pierwszych latach istnienia Festiwalu - miały wszak pokazać tę jasną stronę życia. Dyrekcja Teatru podjęła jednak decyzję, iż takie ujęcie staje się niewystarczające, a nadmiar komedii zaczyna przynosić publiczności uczucie znużenia i przesytu.

18 Jacek Sieradzki, Teatr ściętej głowy, „Polityka” 2000, nr 18, cyt za: wortal www.e-teatr. pl, http://www.e-teatr.pl/pl/artykuly/88506.html (dostęp: 14.04.2016).

19 Zob.: Ewa Pilawska, Koncepcja programowa Teatru Powszechnego w Łodzi [broszura], Łódź, maj 2015, s. 2. 
W ciągu ośmiu lat Festiwal wyrobił sobie dobrą, lecz jednocześnie zobowiązującą markę. Mimo trudnych początków i ciągle skromnej dotacji udało się z sukcesem wprowadzić inicjatywę Powszechnego w życie kulturalne Łodzi. Ewa Pilawska w wywiadzie dla „Gazety Wyborczej” w 1999 roku podkreślała, że Festiwal także w całej Polsce odbierany jest z dużą sympatią. O ogromnym wręcz zainteresowaniu przeglądem wśród tódzkiej publiczności najlepiej świadczyły tłumy widzów, szczelnie wypełniające widownię Powszechnego; podczas piątej edycji brakowało nie tylko miejsc siedzących czy dostawianych, ale również stojących ${ }^{20}$.

Truizmem jest konstatacja, iż wszystko musi ewoluować i przemieniać swą postać, niemniej losy Festiwalu tę starą prawdę spektakularnie potwierdzają. W roku 2003, czyli w trakcie liczbowo „magicznego" 21 9. Festiwalu, zmiana formuły wydarzenia stała się faktem. Do jego nazwy dodano drugą część dokonanego przez Shawa podziału dramatów, dzięki czemu przegląd zyskał miano Ogólnopolskiego Festiwalu Sztuk Przyjemnych i Nieprzyjemnych. Wraz z takim przeistoczeniem mógł czerpać jeszcze głębiej z konceptu Shawa i swobodnie prezentować, obok komedii, utwory znacznie poważniejsze, co ogromnie poszerzyło i zróżnicowało jego repertuar. Stworzyło to także perspektywę dla coraz śmielej podejmowanych inicjatyw: aranżowania wydarzeń artystycznych, zamawiania dzieł teatralnych, inicjowania refleksji krytycznej i naukowej. Przyniosło też zmiany organizacyjne - Plebiscyt Publiczności wyłaniał odtąd: Najlepszą Aktorkę, Najlepszego Aktora i Najlepszy Spektakl. Przeglądowi zaczęly towarzyszyć spotkania z twórcami przedstawień, które prowadzili w Klubie Festiwalowym (otwieranym po spektaklach w przestrzeni foyer i kawiarni Powszechnego) studenci łódzkiej teatrologii. Grupa skupiona w Studenckim Kole Naukowym Teatrologów przy Katedrze Dramatu i Teatru Uniwersytetu Łódzkiego stworzyła też okolicznościową gazetę: „Karty Festiwalowe”, zawierającą omówienia dramatów, recenzje spektakli, wywiady $\mathrm{z}$ artystami, sondy prowadzone wśród widzów i relacje z życia festiwalowego. Początkowo, gdy spektakle prezentowane były tylko w kolejne weekendy, biuletyn wydawany był zgodnie z zasadą: ,jeden numer gazety na jeden spektakl", ale wobec intensyfikowania się tygodniowego rytmu festiwalowych prezentacji i ta zasada była modyfikowana. „Karty Festiwalowe” przetrwały kilka lat. Później ich funkcje zaczęly przejmować spotkania prowadzone przez krytyków sztuki, a także okolicznościowe dodatki do lokalnych gazet

20 Zob. Ewa Pilawska, rozmowa z Anną Płażewską...

21 Na magiczne konteksty cyfry 9 powoływali się sami organizatorzy Festiwalu, zob.: Archiwum cyfrowe Teatru Powszechnego w Łodzi - 9. Ogólnopolski Festiwal Sztuk Przyjemnych i Nieprzyjemnych (2003 r.), https://powszechny.pl/en/9-ogolnopolskifestiwal-sztuk-przyjemnych-i-nieprzyjemnych-2003-r-en/ (dostęp: 20.09.2016). 
i cykle programów w mediach (np. studia festiwalowe prowadzone w TVP3 przez redaktor Krystynę Piaseczną).

W czasie 9. Festiwalu radykalnie zmieniła się również oprawa i aranżacja plastyczna wydarzenia. Do współpracy z Teatrem Powszechnym zaczęto zapraszać najlepszych polskich plastyków, którzy przygotowywali oryginalne plakaty do kolejnych edycji Festiwalu. Ich dzieła pojawiały się też w wielu festiwalowych wydawnictwach - w starannie odtąd redagowanych programach, na ulotkach i w różnego typu drukach reklamowych, a także w informacjach medialnych. Trzeba podkreślić, że ten sposób wizualnej identyfikacji Festiwalu w pierwszym dziesięcioleciu XXI wieku utrzymany był na najwyższym poziomie artystycznym i poligraficznym. Pierwszy plakat, do 9. Festiwalu, stworzył czołowy artysta Polskiej Szkoły Plakatu, świetny malarz, scenograf, grafik, kaligrafista, a także legenda artystycznej bohemy - Franciszek Starowieyski. Praca, zrealizowana we właściwej dla Starowieyskiego barokowej stylistyce, przedstawia dwie, stojące naprzeciwko siebie, hybrydyczne, groteskowo wyobrażone i podlegające anatomicznej transformacji postaci kobiece w maskach przywiązanych do twarzy/czaszki - co niezwykle ekspresyjnie oddaje także charakter wieloznacznej poetyki inicjowanej właśnie formuły Festiwalu Sztuk Przyjemnych i Nieprzyjemnych ${ }^{22}$. Festiwal zyskał też, pożyczone od rodzimej sceny, wyraziste logo w postaci spiralnej woluty, które jako symboliczny detal, manifestujący obecność we wszystkich wydarzeniach organizatora - Teatru Powszechnego - towarzyszyło jego nazwie i liczbie.

Od ósmej edycji utrwalił się zwyczaj zapraszania Gościa Specjalnego Festiwalu. W czasie edycji dziewiątej był to znakomity muzyczny spektakl, zaproponowany przez Wojciecha Waglewskiego, a wyreżyserowany przez Piotra Cieplaka w warszawskim Teatrze Studio, z udziałem Jana i Marii Peszków, z grającym na żywo zespołem Voo Voo. Artyści wykonywali teksty napisane przez uczniów Zespołu Szkół Specjalnych nr 11 w Krakowie, do których muzykę skomponował Waglewski. Widowisko, zatytułowane Muzyka ze stowami, zabierało publiczność „[...] w krzepiącą podróż wyobraźni, gdzie kipi od surrealistycznych skojarzeń, piramidalnego humoru i bolesnych zagadek" 23 , co wpisywało się doskonale w kreowaną poetykę Festiwalu.

W swojej ofercie konkursowej 9. Festiwal przyniósł już bardzo wyraźną dwubiegunowość propozycji teatralnych. Do grupy Sztuk Przyjemnych można było zaliczyć przedstawienie przygotowane przez gospodarzy - opartą na starym

22 Zob. fotografia plakatu w programie i na stronie Teatru Powszechnego, https:// powszechny.pl/pl/9-ogolnopolski-festiwal-sztuk-przyjemnych-i-nieprzyjemnych2003-r (dostęp: 19.09.2016).

23 Za: strona zespołu Voo Voo, http://www.voovoo.pl/muzslo.html (dostęp: 18.09.2016). 
chwycie przebieranki komedię amerykańskiego dramaturga i scenarzysty Kena Ludwiga Pót żartem, pót sercem. Tradycja prezentowania przez Powszechny na Festiwalu sztuk premierowych została tym samym „zintensyfikowana”, bowiem sztuka (oryginalny tytuł Leading Ladies, tłumaczenie Elżbieta Woźniak) została zrealizowana przez Marcina Sławińskiego jako prapremiera światowa (2 XI 2002), jeszcze przed jej premierą w Londynie. W zespole utworów „przyjemnych" mieścił się także spektakl Niespodziewany koniec lata, będący inscenizacją jednego z wieczorów Kabaretu Starszych Panów Jeremiego Przybory i Jerzego Wasowskiego (reż. Śmigasiewicz, Teatr Miejski im. Witolda Gombrowicza, Gdynia; za rolę Jesiennej Dziewczyny i Biduli Tytuł Najlepszej Aktorki otrzymała Dorota Lulka), oraz - już nie tak melancholijny - słynny Testosteron Andrzeja Saramonowicza (reż. Glińska, Teatr Montownia, Warszawa). Śmiech i poczucie tragizmu, liryzm, ironia i czarny humor jeszcze intensywniej splatały się w kolejnej inscenizacji Agnieszki Glińskiej - w spektaklu Bambini di Praga według opowiadania/minipowieści Bohumila Hrabala (Teatr Współczesny, Warszawa). Przedstawienie uhonorowane zostało Tytułem Najlepszego Spektaklu Festiwalu i świetnie wpisywało się w jego nowo ustanawianą dwuwartościową zasadę estetyczną. Ambiwalentne uczucia budził także Samotny zachód Martina McDonagha (reż. Korin, Teatr Nowy, Poznań), jedna z części trylogii (obok Królowej piękności $z$ Leenane i Czaszki z Connemary) młodego irlandzkiego dramatopisarza, którego twórczość zyskiwała właśnie duże uznanie na polskich scenach. Kolejne dwie propozycje sytuowały się już zdecydowanie po stronie Sztuk Nieprzyjemnych: Matka Joanna od Aniotów, opracowana przez Marka Fiedora, przejmująca adaptacja opowiadania Jarosława Iwaszkiewicza, w której reżyser „pytał o źródła zła w dzisiejszym katolickim, bogobojnym społeczeństwie"24 (Teatr im. Jana Kochanowskiego, Opole) oraz Kto się boi Virginii Woolf? Edwarda Albee'go, teatralny debiut reżyserski Władysława Pasikowskiego (Teatr Powszechny, Warszawa) z gwiazdorską obsadą: Krystyna Janda (Martha) i Marek Kondrat (George). Artyści za swoje kreacje otrzymali Tytuły Najlepszej Aktorki (Janda ex aequo z Dorotą Lulką) i Najlepszego Aktora.

Podsumowując dziewiąty, przełomowy Festiwal Ewa Pilawska konstatowała:

Tegoroczna edycja utwierdziła mnie w słuszności decyzji o zmianie dotychczasowej formuly. Siła teatru polega na wiecznym poszukiwaniu, dążeniu, zadawaniu pytań. Teatr nie może być letni, musi pulsować, dotykać, pobudzać. Po latach kształtowania Festiwalu stanęłam przed bardzo wyraźnym wyborem: albo będę

24 Roman Pawłowski, W telewizji pokaża, „Gazeta Wyborcza” 2006, nr 131, cyt. za: wortal www.e-teatr.pl, http://www.e-teatr.pl/pl/artykuly/26535.html (dostęp: 20.08.2016). 
kontynuować bezpieczną drogę, albo otworzę nowe przestrzenie, gdzie nie będzie już tak bezpiecznie, ale za to na pewno ciekawiej i bardziej twórczo. Wybór był dla mnie oczywisty 25 .

Zasadność tego wyboru potwierdziła publiczność, która niezmiennie tłumnie towarzyszyła wszystkim festiwalowym wydarzeniom, a także Specjalna Nagroda Wielkiej Kapituły Loży Przyjaciół Teatru Powszechnego, przyznana w czerwcu 2003 roku: „za przywrócenie wartości Teatru Powszechnego”26.

Jubileuszowy 10. Festiwal - w styczniu i w lutym roku 2004 - przyniósł kolejne znaczące nowe wydarzenia. Po raz pierwszy pojawił się na nim Gość Specjalny z zagranicy. Był to Petr Zelenka, czeski dramaturg, scenarzysta i reżyser, twórca m.in. „kultowych” filmów: Guzikowcy, Samotni czy Rok diabła, a także autor świetnej „czarnej komedii” Př̉běhy obyčejného šilenství (Opowieści o zwyczajnym szaleństwie). I właśnie prapremierową (z 2001 r.) autorską realizację tej tragikomedii z praskiego teatru Dejvické Divadlo lódzka publiczność mogła obejrzeć na 10. Festiwalu. Ewa Pilawska zapowiedziała też rychłą realizację w Teatrze Powszechnym jej polskiej wersji, co też się stało: Waldemar Śmigasiewicz pokazał ją tu już w kwietniu tego roku (tł. Krystyna Krauze).

Ale najważniejszym wydarzeniem 10. Festiwalu niewątpliwie byłudział w nim jednego z najwybitniejszych polskich i europejskich artystów - Krystiana Lupy, który przedstawił tu dwie swoje słynne inscenizacje zrealizowane w Narodowym Starym Teatrze im. Heleny Modrzejewskiej w Krakowie: Kalkwerk i Rodzeństwo. Obie były adaptacjami prozy Thomasa Bernharda i choć nie były nowościami - Kalkwerk mial premierę w roku 1992 (w 2003 r. spektakl został wznowiony na krakowski „Lupa festiwal”), a Rodzeństwo (Ritter, Dene, Voss) w 1996 roku (przygotowane na Scenie Kameralnej przez lata było w jej repertuarze) - ich wybór był znaczący. Przedstawienia te niezmiennie stanowiły reprezentatywne przykłady twórczości Krystiana Lupy, będącej dla odbiorców prawdziwym intelektualnym i etycznym wyzwaniem. Towarzyszyło im w Łodzi spotkanie z artystą oraz wernisaż jego rysunków i szkiców - obydwie imprezy zostały zorganizowane w Galerii Opus Film. Poszerzanie przestrzeni i formy odbywania się Festiwalu to także znamienna nowość wprowadzona przez organizatorów, kontynuowana w kolejnych latach. Przygotowywanie ciekawej oferty imprez partnerujących przeglądowi spektakli pozwalało m.in. przenieść uwagę z kontemplacji sztuki aktorskiej

25 Ewa Pilawska, wypowiedź, „Kalejdoskop”, marzec 2003, za: Archiwum cyfrowe Teatru Powszechnego w Łodzi, https://powszechny.pl/pl/9-ogolnopolski-festiwalsztuk-przyjemnych-i-nieprzyjemnych-2003-r/ (dostęp: 30.08.2021).

26 Zob. 'Ewa Pilawska', strona Teatru Powszechnego w Łodzi, https://powszechny. $\mathrm{pl} / \mathrm{pl} /$ zespol-administracyjny/ewa-pilawska/ (dostęp: 20.09.2016). 
gwiazd polskiego teatru na zjawiska interdyscyplinarne o szerszym znaczeniu kulturowym. Było także znakiem coraz intensywniejszej współpracy Festiwalu z innymi instytucjami - łódzkimi, polskimi i zagranicznymi - które odtąd wytrwale i w coraz liczniejszej grupie towarzyszyły Festiwalowi (obok Galerii Opus Film czy Uniwersytetu Łódzkiego były to m.in.: Klub Wytwórnia, Miejska Galeria Sztuki, uczelnie artystyczne, ambasady i Instytuty Kultury obcych państw itd.). Wizyta w Łodzi tak wybitnego artysty jak Krystian Lupa podkreślała rosnący status Festiwalu i wyznaczała standardy na najbliższe lata. Publiczność doceniła nadzwyczajną wartość legendarnych widowisk, nagradzając Kalkwerk Tytułem Najlepszego Spektaklu. Przedstawienie otrzymało także nagrodę Wydarzenie Festiwalu przyznaną przez Wielką Kapitułę Loży Przyjaciół Teatru Powszechnego. Za fenomenalnie zagraną rolę Konrada w Kalkwerku mianem Najlepszego Aktora widzowie obdarowali Andrzeja Hudziaka.

Choć prezentacja twórczości Krystiana Lupy była propozycją na najwyższym poziomie atrakcyjności teatralnej, stanowiła tylko jeden z elementów 10. Festiwalu. Już inicjujący go spektakl Jarzyny (występującego pod pseudonimem artystycznym H7) - Uroczystość z TR Warszawa, był przeżyciem bezprecedensowym. Utwór oparty został na sławnym filmie Festen Thomasa Vintenberga i Mogensa Rukova z duńskiej Dogmy i oszałamiał publiczność, tak z powodu siły ataku na hipokryzję i obłudę rodzinnego/ społecznego życia, jak i z powodu wybornych kreacji aktorskich zespołu artystów, których skład - jak pisali krytycy - „zapiera dech w piersi"27. Tworzyli tę grupę m.in.: Jan Peszek, Andrzej Chyra, Ewa Dałkowska, Danuta Szaflarska, Gustaw Lutkiewicz, Danuta Stenka, Magdalena Cielecka, Aleksandra Konieczna, Aleksandra Popławska, Marek Kalita. Zachwycała w przedstawieniu także scenografia Małgorzaty Szczęśniak i muzyka Pawła Mykietyna.

Kolejni goście jubileuszowego Festiwalu również proponowali sztuki z kategorii „nieprzyjemnych”. Działająca głównie w teatrach londyńskich, ale doceniana także za granicą inscenizatorka polskiego pochodzenia, uczennica Erwina Axera i Bohdana Korzeniewskiego - Helena Kaut-Howson - pokazała Zwycięstwo Howarda Bakera, jednego z czołowych współczesnych dramaturgów brytyjskich. Reżyserka, operując poetyckim i okrutnym jednocześnie wyobrażeniem (pozornie) XVIII-wiecznego świata „[...] stworzyła porywające trzyipółgodzinne widowisko" 28 z Danutą Stenką w jednej z głównych ról - wdowy Bradshaw

27 Zob. Piotr Gruszczyński, Czcij ojca swego, „Tygodnik Powszechny” 2001, nr 25, za: wortal www.e-teatr.pl, http://www.e-teatr.pl/pl/artykuly/136967,druk.html (dostęp: 20.09.2016).

28 Jacek Cieślak, Hiobowe wieści dla scenicznych monopoli, za: wortal www. encyklopediateatru.pl, http://encyklopediateatru.pl/artykuly/6768/hiobowe-wiesci-dlascenicznych-monopoli (dostęp: 19.09.2016). 
- za którą artystka, wraz z kreacją postaci Helene w Uroczystości, została uznana za Najlepszą Aktorkę Festiwalu. Tragifarsę Szpital Polonia, która „[... niezwykle trafnie, błyskotliwie i boleśnie opisywała polską potransformacyjną rzeczywistość" 29 pokazał reżyser i dramaturg Paweł Kamza. Swoją sztukę artysta przygotował w radykalnym Teatrze im. Heleny Modrzejewskiej w Legnicy, który pierwszy raz odwiedził lódzki Festiwal.

Pozostały repertuar 10. Festiwalu pomyślany został jako mniej krytyczny, co nie znaczy - na niższym poziomie artystycznym. Marcin Sławiński zaskoczył wielbicieli swojego talentu, prezentując nie farsę, lecz mroczną, polityczno-społeczną sztukę z kręgu teatru faktu, dotykającą rzeczywistości PRL-u, czyli utwór Wampir - debiut Wojciecha Tomczyka, scenarzysty i dramatopisarza (Teatr Nowy, Zabrze). Drugi z „żelaznej” grupy reżyserów Festiwalu - Eugeniusz Korin - powtórzył swój pomysł na Piękną Lucyndę Hemara (oglądaną na 1. Festiwalu), przygotowując ją tym razem z zespołem gospodarzy. Podobnie po raz wtóry lódzka publiczność mogła zobaczyć słynną farsę Czego nie widać, której nową wersję zaproponował Juliusz Machulski, obsadzając spektakl gwiazdami z warszawskiego Teatru Powszechnego (m.in. Zbigniew Zapasiewicz, Krystyna Janda, Kazimierz Kaczor, Katarzyna Herman, Agnieszka Krukówna, Szymon Bobrowski, Rafał Królikowski). W doskonały ansambl z warszawskiego Teatru Współczesnego wyposażył także Maciej Englert romantyczną i groteskową komedię Kay Mellor pt.: Namiętna kobieta. W spektaklu grali m.in.: Krzysztof Kowalewski, Piotr Adamczyk, Andrzej Zieliński i - jako Betty - Marta Lipińska, która stworzyła w nim wspaniałą tytułową postać „namiętnej kobiety”, co publiczność nagrodziła laurem Najlepszej Aktorki (ex aequo z Danutą Stenką).

Do edycji dziesiątej plakat został zaprojektowany przez innego twórcę Polskiej Szkoły Plakatu, światowej sławy malarza i grafika - Rafała Olbińskiego. Dzieło przedstawiało wizerunki trzech kobiet (czy raczej potrojony wizerunek jednej kobiety), których układ przypominał trochę rosyjską matrioszkę, gdyż w większej postaci znajdowała się mniejsza, a w niej jeszcze mniejsza kobieta, i im postać stawała się mniejsza, tym bardziej była obnażona. Można ów plakat interpretować na wiele sposobów, ale z pewnością jedną z najbardziej oczywistych refleksji jest taka, iż sztuka jest wielowarstwowa, a dostrzeżenie tego, co najważniejsze, czasami wymaga zajrzenia głębiej, poza zewnętrzną formę i jej kostium.

Przebieg Festiwalu w następnych latach polegał na zachowaniu podstaw jego wypracowanej struktury organizacyjnej, ale z systematyczną modyfikacją jej kształtu. Nowy wariant wydarzenia przyniósł już 11. Festiwal w 2005 roku. Od tej edycji Festiwal jest profilowany zgodnie z proponowanym przez organizatorów

29 Monika Mokrzycka-Pokora, 'Paweł Kamza', wortal: www.culture.pl, https:// culture.pl/pl/tworca/pawel-kamza (dostęp: 30.08.2021). 
wiodącym tematem spotkania. „Każdorazowo temat Festiwalu - wyjaśnia Ewa Pilawska - jest odpowiedzią na wydarzenia i zjawiska ważne w życiu teatralnym i społecznym w poprzedzającym go czasie" 30 . Hasło przewodnie, mające zapewnić spójność programową, traktowane jest jednak na tyle szeroko, by dało się w nim pomieścić drugie (a właściwie ciągle pierwsze) kryterium selekcjonowania spektakli, czyli ich status wybitnych artystycznie i prowokujących intelektualnie nowych wydarzeń w polskim życiu teatralnym.

Tematem 11. Festiwalu była problematyzacja sytuacji egzystencjalnej człowieka. Proponowane spektakle, jak pisali organizatorzy, to teatralne wypowiedzi „[...] o naszej kondycji, o tym, że istotą naszego bytu jest potrzeba ducha i o tym, jak wikłamy się w zewnętrzność $[\ldots]$ ".. 31 . W tak formułowane zagadnienie wpisały się cztery widowiska przygotowane przez stołeczne sceny, na czele z Teatrem Narodowym, który pokazał gorzką i przenikliwą obyczajowo pierwszą sztukę teatralną Jerzego Pilcha - Narty Ojca Świętego, w reżyserii Piotra Cieplaka. W autoprezentacji utworu Pilch pisa1: „[... [ Zadaję pytanie: Co się dzieje z ludźmi? Co się dzieje z ludźmi, gdy w poważny, mniej poważny, albo nawet $\mathrm{w}$ śmiertelnie poważny sposób zaczynają o papieżu, o obecności papieża w ich życiu, myśleć?"32. W sztuce zagrała gwiazdorska obsada, z Januszem Gajosem (za rolę księdza Kubali otrzymał Tytuł Najlepszego Aktora), Władysławem Kowalskim, Jerzym Radziwiłowiczem i Jarosławem Gajewskim na czele. Równie wytrawny aktorsko był zespół Teatru Ateneum, który przywiózł przygotowany na 75-lecie sceny swój jubileuszowy spektakl - Króla Edypa Sofoklesa, w reżyserii Gustawa Holoubka. Główne role w spektaklu kreowali: Piotr Fronczewski, Teresa Budzisz-Krzyżanowska, Jerzy Trela, Krzysztof Gosztyła, Jerzy Kamas. Teatr Dramatyczny pokazał kolejną inscenizację Marka Fiedora - Samobójcę Nikołaja Erdmana, sztukę powstałą w 1928 roku, ale - jak zauważał Roman Pawłowski: „Na spektakl w Dramatycznym powinny ustawiać się kolejki, ponieważ Fiedor pokazuje nam, dokąd doszliśmy jako społeczeństwo. I czyni to bardziej wnikliwie niż większość naszych polityków"33, a po obejrzeniu łódzkiej prezentacji Leszek Karczewski

30 Ewa Pilawska, Koncepcja programowa ..., s. 14, cyt. za: https://bip.uml.lodz. $\mathrm{pl} /$ files/bip/public/BIP_AB/MJO_apd_teatr_powszechny_181113.pdf (dostęp: 20.08.2016).

31 Ewa Pilawska, tekst programowy 11. Festiwalu, [w: ] XI Ogólnopolski Festiwal Sztuk Przyjemnych i Nieprzyjemnych, red. Joanna Olczakówna, Teatr Powszechny w Łodzi, Łódź 2005, s. 3.

32 Jerzy Pilch, Narty Ojca Świętego, Świat Książki, Warszawa 2004, s. 7.

33 Roman Pawłowski, Polska bezrobotna, „Gazeta Wyborcza” 2004, nr 151, wortal: www.encyklopediateatru.pl, http://www.encyklopediateatru.pl/artykuly/2789/ polska-bezrobotna (dostęp: 19.09.2016). 
dopowiadał: „Wszystkie etiudy, znakomicie czytelne osobno, składały się na rewelacyjny portret polskiej degrengolady" 34 . Za wspaniale zagraną rolę Marii w tym spektaklu Tytułem Najlepszej Aktorki została wyróżniona Gabriela Muskała. Cierpkim i groteskowym zarazem dyskursem na temat współczesności były też - różne treściowo, gatunkowo i stylistycznie, lecz porównywalne swoją poznawczą przenikliwością: Wyzwolenie Stanisława Wyspiańskiego w inscenizacji Anny Augustynowicz (Teatr Współczesny ze Szczecina), rzecz „[... o o Polsce dzisiejszej. Wyzwolonej narodowo, ale zniewolonej mitami. Schwytanej w pułapkę marnych gestów"35; Pawła Miśkiewicza premierowa w Polsce realizacja znakomitej sztuki Dei Loher Niewina w Narodowym Starym Teatrze w Krakowie - nagroda dla Najlepszego Spektaklu; czy wirtuozersko zagrane trzy jednoaktówki Samuela Becketta (Katastrofa, Impromptu „Ohio” i Ostatnia taśma) przygotowane przez Antoniego Liberę w warszawskim Teatrze Powszechnym jako spektakl - Zapasiewicz gra Becketta, na jubileusz 70. urodzin i 50-lecia pracy artystycznej mistrza polskiej sztuki aktorskiej. Ponadto festiwal gościł Teatr Jeleniogórski z miniaturami dramatycznymi Dialogi o zwierzętach Aleksandra Żelezcowa (reż. Krzysztof Rekowski) i właśnie to przedstawienie otrzymało nagrodę Kapituły Loży Przyjaciół Teatru Powszechnego (materialnym wyrazem uznania Kapituły była rzeźba Jacka Sibilskiego). Po raz pierwszy zaprezentował się na Festiwalu częstochowski Teatr im. Adama Mickiewicza - z eklektyczną gatunkowo, zabawną Skrzyneczka bez pudła, adaptacją opowiadania Wiesława Dymnego (reż. Andrzej Sadowski). Zespół gospodarzy zaprezentował natomiast Testosteron Saramonowicza w nowej reżyserii Norberta Rakowskiego. Jak widać, przewaga sztuk krytycznych, interpretujących rzeczywistość i naszą w niej rolę, była już znacząca. Podobnie przebiegały kolejne festiwale, które - zgodnie ze wstępną deklaracją organizatorów - przyjemność pojmowały jako satysfakcję uczestniczenia w doskonałym artystycznie i dociekliwym poznawczo wydarzeniu teatralnym.

Plakat do jedenastej edycji został zaprojektowany przez znanego artystę grafika Andrzeja Pągowskiego i przedstawiał rysunkowo i malarsko niezwykle śmiało zobrazowane dwie kobiece postaci. Ich twarze - w charakterystyczny dla sztuki Pągowskiego sposób - uległy transformacji i destrukcji. Zamykają i przesłaniają je martwe formy (maski?), które, uwyraźniają ich drapieżnie ukazane usta $-\mathrm{u}$ jednej z postaci wykrzywione $\mathrm{w}$ grymasie, u drugiej rozciągnięte w szerokim

34 Leszek Karczewski, Po trupach do celu, „Gazeta Wyborcza - Łódź” 2005, nr 33, cyt. za: wortal www.e-teatr.pl, http://www.e-teatr.pl/pl/artykuly/8767.html (dostęp: 18.08.2016).

35 Artur D. Liskowacki, Tragiczna groteska polskości, „Przekrój”, cyt. za: XI Ogólnopolski Festiwal Sztuk Przyjemnych i Nieprzyjemnych [program], red. Joanna Olczakówna, Teatr Powszechny, Łódź 2005, s. 20. 
uśmiechu. Po raz kolejny plakat symbolicznie oddawal „przyjemność” oraz „nieprzyjemność" obcowania ze sztukami granymi podczas festiwalu.

Tej edycji towarzyszyło również nadzwyczajne wydarzenie związane z prezentacją nowej, malowanej kurtyny, która była prezentem od łódzkiego Atlasa Sztuki dla Teatru Powszechnego. Jej projekt wykonał Piotra Naliwajko, a imponująca kurtyna $(4,6$ x 8,2 m) z obrazem artysty pt. Zdumiewająco nieprzemysłowy duch miała zawisnąć w Teatrze Powszechnym w następnym roku. Podczas trwania 11. Festiwalu w foyer Teatru otwarto galerię przedstawiającą projekty kurtyny. Jednocześnie łódzka Galeria Atlas Sztuki przygotowała wystawę prac Naliwajki - Tylko wielkie obrazy36.

Wszystkie kolejne Festiwale kontynuowały formułę przeglądu tematycznego, podejmując propozycje tematów wiodących. Dla 12. Festiwalu takim tematem stała się samotność „[...] od jednostkowej, po doświadczającą człowieka poprzez - mającą ocalać go - sztukę. W swym osamotnieniu, a szczególnie w podejmowaniu z nim walki, człowiek - tak jak teatralny błazen - śmieszy swą nieporadnością i głęboko wzrusza tragizmem swego losu"37. Tak określonej problematyce samotności odpowiadać miało osiem inscenizacji. Janusz Wiśniewski zaproponował swoją autorską - kontrowersyjną - interpretację Fausta Johanna Wolfganga von Goethego (Teatr Nowy w Poznaniu). Łódzka publiczność zobaczyła nowe dzieło Krystiana Lupy, tym razem był to Niedokończony utwór na aktora, przedstawienie przygotowane przez artystę (reżyseria, adaptacja, scenografia i opracowanie muzyczne) na podstawie dwóch sztuk: Mewy (Czajki) Czechowa oraz Sztuki hiszpańskiej Yasminy Rezy, znakomitej francuskiej pisarki (i aktorki). Ze względu na czas trwania spektaklu - sześć godzin - został on podzielony na dwa wieczory. A z powodu wymogów scenograficznych - dla potrzeb inscenizacji trzeba było zbudować na scenie basen na około dwanaście ton wody - przedstawienie zostało przeniesione do Teatru Wielkiego. Jak twierdzi inscenizator: „Mewę i Sztukę hiszpańską łączy to, że zajmują się czymś szczególnie istotnym dzisiaj - problemem prawdy w teatrze" 38 . Tej prawdy artysta poszukuje też w samym fenomenie sztuki teatru i aktorstwa, a wspaniałą realizatorkę swej idei odnalazł w wykonawczyni dwóch głównych ról - Mai Komorowskiej, której kreacje Arkadiny i Pilar przeszły do legendy polskiej sceny, podobnie jak inscenizacja

36 Zob. Katalog wystawy: http://www.atlassztuki.pl/pdf/katalog_9.pdf (dostęp: 20.09.2016).

37 Ewa Pilawska, tekst programowy, XII Ogólnopolski Festiwal Sztuk Przyjemnych i Nieprzyjemnych, red. Patrycja Kruczkowska, Maja Wójcik, Łódź 2006, s. 4.

38 Dorota Wyżyńska, „Niedokończony utwór na aktora...” w Teatrze Dramatycznym, „Gazeta Wyborcza - Warszawa” (30 września 2004), http://warszawa.wyborcza. $\mathrm{pl} /$ warszawa/1,34861,2315945.html?disableRedirects=true (dostęp: 20.09.2016). 
Stomkowego kapelusza przygotowana przez Piotra Cieplaka (Teatr Dramatyczny, Warszawa). Tę klasyczną farsę Eugène’a Labiche’a - wbrew dyspozycjom gatunku - reżyser zinterpretował w perspektywie metafory teatru jako parabolicznej wizji świata. Artysta ujął dzieło w autotematyczną teatralną ramę i jako komentarz dodał do niego fragmenty Ziemi jałowej Thomasa Stearnsa Eliota. W rezultacie powstało dzieło, które - zachowując komiczne elementy widowiska - staje się wypowiedzią głęboko metafizyczną. Publiczność wyróżniła utwór, przyznając mu nagrodę Najlepszego Spektaklu. Trzecią niezwykłą festiwalową propozycją była, utrzymana w radykalnie odmiennej poetyce, autorska realizacja Przemysława Wojcieszka - Made in Poland - z legnickiego Teatru Modrzejewskiej. Emocjonujący prolog spektaklu, w którym bohater, blokers buntownik - skin Boguś (w tej roli świetny Eryk Lubos, nagrodzony Tytułem Najlepszego Aktora) rozbija na parkingu prawdziwy samochód, rozegrał się na placyku przed zamkniętym marketem, nieopodal Powszechnego. Dalsza część spektaklu, przedstawiona na pierwszym piętrze opuszczonego sklepu, była intensywną opowieścią „o pokoleniu »no future «"39, ale taką, w której Wojcieszek „[... ] kapitalnie równoważy zabawę filmowymi kliszami i interwencyjnie ukazane społeczne tło" 40 , wzbudzając silne reakcje publiczności, bowiem „[... ] niby-realistyczna historia Bogusia jest w istocie piękną przypowieścią o Polsce" 41 . Nowością w dziejach przeglądu był - po raz pierwszy konkursowy, a nie gościnny - udział w Festiwalu zagranicznego przedstawienia: spektaklu Nieprawdopodobne spotkanie (Improbable rencontre) francuskiego reżysera Alaina Mollota z paryskiego Théâtre de la Jacquerie. Kameralna propozycja przygotowana została na podstawie rodzinnych opowieści dwojga występujących w niej aktorów: Henriego Kochmanna i Yoli Buszko. Gospodarze Festiwalu pokazali, wspomnianą wcześniej, swoją wersję Opowieści o zwyczajnym szaleństwie Zelenki w reżyserii Śmigasiewicza.

Dwunastą edycję przeglądu reprezentował plastycznie plakat stworzony przez kolejnego wybitnego artystę - Stasysa Eidrigevičiusa. Ten pochodzący z Litwy grafik, malarz, rysownik, rzeźbiarz, twórca exlibrisów, ilustracji, także fotografik, scenograf oraz autor sztuk teatralnych, happener i performer o bardzo rozpoznawalnym stylu twórczości, przygotował plakat, który przedstawia - symbolistycznie i surrealistycznie wyobrażony - portret uśmiechniętej twarzy.

39 Roman Pawłowski, „Gazeta Wyborcza”, cyt. za stroną Teatru Modrzejewskiej w Legnicy, https://www.teatr.legnica.pl/spektakle/archiwalne/item/28-made-in-poland (dostęp: 20.09.2016).

40 Leszek Karczewski, Tragedia $z$ blokowisk, „Gazeta Wyborcza - Łódź” 2006, nr 31, cyt. za: wortal www.e-teatr.pl, http://www.e-teatr.pl/pl/artykuly/21654.html (dostęp: 20.08.2016).

41 Ibidem. 
Wizerunek stanowi kompozycję figuralną, zbudowaną z dwóch bliźniaczych, uproszczonych w rysunku, sylwetek ludzkich postaci: jednej radosnej, drugiej smutnej. Praca znakomitego, „pogodnego mądrym smutkiem” 42 , artysty wybornie oddawała ideę Festiwalu.

Wyrazem ewolucji formuly Festiwalu - i ciągłego poszukiwania nowych sposobów prowadzenia rozmowy z publicznością - było zorganizowanie w ramach jego dwunastej edycji minifestiwalu Krystyny Jandy pt. $5 x$ Janda. Na tę tytułową „piątkę” składały się dwa autorskie spektakle artystki: monodram w jej wykonaniu, oparty na powieści chorwackiej autorki Vedrany Rudan - Ucho, gardło, nóż (za rolę Tonki Babić Krystyna Janda otrzymała Tytuł Najlepszej Aktorki) oraz wyreżyserowana przez nią sztuka Dubravki Ugrešić Stefcia Ćwiek w szponach życia (obydwa utwory - Teatr Polonia). Do festiwalowych wydarzeń dołączyły też: wystawa portretów fotograficznych aktorki w Galerii Opus; przegląd filmów z jej udziałem (połączony z rozmową z trójką ważnych dla rozwoju kariery artystki reżyserów: Andrzejem Barańskim, Ryszardem Bugajskim i Andrzejem Wajdą - w Kinie Charlie) oraz spotkanie z Krystyną Jandą - pisarką (księgarnio-kawiarnia „mała litera”). Jak widać, wewnętrzna przemiana Festiwalu polegała nie tylko na poszerzeniu i zróżnicowaniu towarzyszących mu imprez, ale także na angażowaniu do współpracy coraz znaczniejszej grupy partnerów spośród instytucji kulturalnych w mieście. Podobny przebieg Festiwalu będzie odtąd jego charakterystyczną cechą.

Dalsze dojrzewanie formy Festiwalu zaprezentowała jego trzynasta edycja w 2007 roku. „Festiwal jako jeden z przejawów działania teatru - pisała w witającym publiczność tekście programowym dyrektor Pilawska - każe traktować sztukę sceny całościowo, spajać różne działania sceniczne, parateatralne, akcje o wymiarze artystyczno-społecznym" 43 . W czasie 13 . Festiwalu odbyły się dwa takie nowe znaczące, towarzyszące przeglądowi wydarzenia. Po pierwsze, przy współpracy Miejskiej Galerii Sztuki w Łodzi, przygotowano wystawę Zbigniew Herbert. Rysunki, którą w pięknym budynku Galerii Willa otworzyła 16 lutego 2007 roku pani Katarzyna Herbert. Po drugie zaś, obok tradycyjnie prowadzonych przez studentów teatrologii UŁ spotkań w z twórcami w Klubie Festiwalowym (po każdej z pierwszych prezentacji spektakli) - osobny cykl spotkań z artystami obecnymi na Festiwalu prowadzili krytycy sztuki w księgarnio-kawiarnii „mała litera”.

Tematem przewodnim Festiwalu w 2007 roku było „[... ] zdejmowanie masek, których właściwością jest nie tylko kamuflowanie, ale i odsłanianie prawdy

42 Za: 'Stasys Eidrigevičius', wortal: Culture.pl, https://culture.pl/pl/tworca/ stasys-eidrigevicius (dostęp: 20.09.2016).

43 Ewa Pilawska, tekst programowy, XIII Ogólnopolski Festiwal Sztuk Przyjemnych i Nieprzyjemnych, red. Maja Wójcik, Łódź 2007, s. 3. 
o człowieku"44. Interpretację zjawiska dwuznaczności maski podejmował także towarzyszący tej edycji plakat, tym razem autorstwa Waldemara Świerzego, wspóltwórcy Polskiej Szkoły Plakatu, jednego z najwybitniejszych polskich plakacistów. Artysta ekspresyjnie posługując się dynamiczną, swobodną plamą barwną, przedstawił uproszczony wizerunek uśmiechniętej twarzy. Jednak grymas przebijający przez ów uśmiech, który prowokacyjnie odsłania braki w uzębieniu, a także zmrużone oko oraz cyrkowa, operująca kiczem stylistyka plakatu, oddają istotę fenomenu maski i jednocześnie tytułową, festiwalową „przyjemność” i „nieprzyjemność”.

W powitaniu widzów Ewa Pilawska wspomniała, iż łódzki Festiwal został właśnie uznany $\mathrm{w}$ mediach za jedno $\mathrm{z}$ najważniejszych wydarzeń teatralnych w Polsce. Dyrektor artystyczna zaznaczyła jednocześnie, że to zasługa publiczności, która bierze czynny udział w przeglądzie, i dzięki jej zaufaniu do działań organizatorów w łódzkim Teatrze Powszechnym, będącym przecież sceną komediową, „, $[.$.$] może rozwijać się festiwal wielu gatunków teatralnych” 45$. Trzynasta edycja tę bezwarunkową akceptację widzów wystawiła na kolejną próbę, zmienił się bowiem rytm festiwalowych prezentacji; obok tradycyjnych już spektakli weekendowych przegląd odbywal się teraz także w ciągu tygodnia, co dwa dni. Ale z pewnością największym sprawdzianem dla lojalności widzów była zmiana propozycji repertuarowych.

Podczas 13. Festiwalu Powszechny gościł artystę z Wielkiej Brytanii - Guya Mastersona, który przyjechał do Łodzi ze swoim monodramem Under Milk Wood wg Dylana Thomasa, w reżyserii Tony’ego Bonczy. Oprócz niego pojawiło się kilkoro znanych z poprzednich edycji artystek i artystów, czy wręcz już „stałych bywalców” łódzkiego przeglądu. Z przedstawionych spektakli większość stanowiły najważniejsze premiery minionego sezonu teatralnego lub zupełnie nowe propozycje wybitnych twórców. Otworzył Festiwal Antoni Libera arcydziełem dwudziestowiecznej dramaturgii - Czekając na Godota Becketta (z udziałem Jerzego Radziwiłowicza, Jarosława Gajewskiego, Zbigniewa Zamachowskiego i Wojciecha Malajkata, który za rolę Vladimira otrzymał Tytuł Najlepszego Aktora). Przedstawienie zostało zrealizowane w Teatrze Narodowym w 2006 roku - roku obchodów setnej rocznicy urodzin Samuela Becketta. Zaledwie miesiąc po premierze łodzianie oglądali też inne znakomite Beckettowskie widowisko, przygotowane przez Piotra Cieplaka Szczęśliwe dni (Teatr Polonia), z kreacjami Krystyny Jandy (Tytuł Najlepszej Aktorki za rolę Winnie) i Jerzego Treli. Anna Augustynowicz pokazała swoją premierową realizację Miarki za miarkę Shakespeare’a (Teatr Powszechny, Warszawa), świetnie wpisującą się w temat

44 Ibidem.

45 Ibidem. 
13. Festiwalu, zaaranżowaną jako rzecz odbywająca się „tu i teraz”, pomiędzy współczesną publicznością. Widzowie docenili kunszt przedstawienia, nagradzając je Tytułem Najlepszego Spektaklu. Spośród szczególnie cenionych w Łodzi reżyserów Powszechny gościł też Marka Fiedora, który z zespołem opolskiego Teatru im. Jana Kochanowskiego przedstawil bardzo mocne widowisko na temat sprzeczności ludzkiej natury, a przygotowane wg Baala Bertolta Brechta. Gospodarzy reprezentował Waldemar Śmigasiewicz, prezentujący na 13. Festiwalu $\mathrm{Na-}$ pis - gorzką, inteligentną komedię o współczesnych „strasznych mieszczanach”, autorstwa francuskiego dramaturga Géralda Sibleyrasa. Ponadto zaprezentowano również trzy przedstawienia młodych polskich reżyserów: wstrząsający Transfer! Jana Klaty (Teatr Współczesny, Wrocław), którego podstawę stanowiły autentyczne wojenne wspomnienia pięciorga Niemców i pięciorga Polaków; brawurową prapremierową polską realizację Mojo Mickybo Owena McCafferty'ego, zaproponowaną przez Wiktora Rubina (Teatr Krypta Zamku Książąt Pomorskich w Szczecinie); oraz Wojnę na trzecim piętrze Pavla Kohouta, wyreżyserowaną przez Pawła Aignera w warszawskim Teatrze Montownia.

Wraz z zakończeniem 13 . Festiwalu znów zamknął się kolejny rozdział w jego historii. Była to bowiem ostatnia odsłona Ogólnopolskiego Festiwalu Sztuk Przyjemnych i Nieprzyjemnych - choć już dwie poprzednie jego edycje wyłamywały się z zakresu prezentacji jedynie rodzimych teatrów, wprowadzając do oficjalnego programu teatry z zagranicy. Aby usankcjonować ów stan, po raz czwarty oficjalnie zmieniono nazwę wydarzenia: w roku 2008 ruszył Międzynarodowy Festiwal Sztuk Przyjemnych i Nieprzyjemnych, który nosi takie miano do dziś. Tak jak w wypadku wszystkich poprzednich modyfikacji konwencji Festiwalu, tak i teraz zachowano chronologiczną numerację i 17 lutego 2008 roku zainaugurowano czternastą edycję przeglądu.

Tematem 14. Festiwalu był „[...] stan wątpliwości, rozumiany jako rodzaj pęknięcia, złamania, który mimo wszystko pozostawia nadzieję" 46 . Jak pisali organizatorzy: „Wątpliwość leży u podstaw naszego człowieczeństwa. Wątpliwość to niezgoda na zastany stan rzeczy, to potrzeba podjęcia ryzyka i otwierania kolejnych drzwi" 47 .

Międzynarodowy charakter tej edycji Festiwalu potwierdzały trzy spektakle. Z Pragi z teatrem Dejvické Divadlo drugi raz przyjechał Petr Zelenka, tym razem przywożąc swoją nową sztukę, pt. Teremin. Była to rzecz o wybitnym rosyjskim

46 Ewa Pilawska, XIV Międzynarodowy Festiwal Sztuk Przyjemnych i Nieprzyjemnych, [program mały], Łódź 2008, s. 2.

47 Ewa Pilawska, tekst programowy, XIV Międzynarodowy Festiwal Sztuk Przyjemnych i Nieprzyjemnych, Łódź 2008, za: https://powszechny.pl/pl/14-miedzynarodowy-festiwalsztuk-przyjemnych-i-nieprzyjemnych-2008-r/ (dostęp: 20.09.2016). 
fizyku Lwie Tereminie ${ }^{48}$, wynalazcy m.in. prototypu telewizora, wysokościomierza magnetycznego, urządzeń do podsłuchiwania, ale także bezdotykowego instrumentu muzycznego, znanego jako theremin (także: eterofon, termenvox/ tereminvox). Losy Teremina, naukowca uwikłanego w sowiecką historię, współpracownika GPU, a jednocześnie prekursora muzyki elektronicznej i jednego z kreatorów popkultury w USA, posłużyły Zelence do zbudowania efektownej tragikomicznej opowieści. Czeskiemu aktorowi Ivanowi Trojanowi, kreującemu rolę Teremina, publiczność przyznała Tytuł Najlepszego Aktora. 14. Festiwal gościł również artystów ze słynnego, choć mieszczącego się w moskiewskiej piwnicy, niezależnego Teatru.doc, który przywiózł aż dwa przedstawienia: Wojnę Mołdawian o tekturowe pudetko Aleksandra Rodionowa, w reżyserii Rusłana Malikowa, Tatiany Kopyłowej i Siergieja Piestrikowa, oraz Błękitnego Ślusarza Michaiła Durnienkowa, w reżyserii dyrektora artystycznego i współtwórcy Teatr.doc - Michaiła Ugarowa oraz Rusłana Malikowa. Teatr.doc to powstały na początku XXI wie$\mathrm{ku}$, szykanowany przez rosyjskie władze, radykalny politycznie teatr non-fiction, pracujący metodą verbatimu, czyli dosłownego zapisu rzeczywistości, zgodnie $\mathrm{z}$ hasłem „teatr, w którym nie grają”. Zarówno tematy (m.in. problem uchodźców z państw postsowieckich, zagadnienie wykluczenia społecznego, alkoholizm), jak i forma prezentacji rosyjskiego teatru były dla łódzkiej publiczności silnym przeżyciem, wzmocnionym jeszcze przez towarzyszący występom artystów, zorganizowany w kinie Cytryna, przegląd filmów o podobnej problematyce. Zespół rosyjski to pierwsza na Festiwalu grupa z obszaru teatru pozainstytucjonalnego.

Inną nowością wprowadzoną w czasie czternastej edycji przeglądu było znaczne poszerzenie wyboru miejsc i przestrzeni prezentacji przedstawień. Wprawdzie już legnickie Made in Poland grane było poza siedzibą Powszechnego, ale dopiero w roku 2008 Festiwal okrzepł na tyle, że mógł z sukcesem przenosić swoje wydarzenia, zgodnie $\mathrm{z}$ ich wymogami, do potężnych czy wyposażonych w niezbędną aparaturę sal. I tak inauguracja Festiwalu, czyli Miłość na Krymie Sławomira Mrożka, w legendarnej reżyserii Jerzego Jarockiego (Teatr Narodowy, Warszawa - Tytuł Najlepszego Spektaklu), odbyła się na ogromnej scenie Teatru Wielkiego w Łodzi. Kolejne widowisko Krystiana Lupy, polska prapremiera sztuki Thomasa Bernharda Na szczytach panuje cisza (Teatr Dramatyczny, Warszawa), zostało zaprezentowane w hali Toya, przy ulicy Łąkowej. A wymagające niekonwencjonalnej przestrzeni Zabijanie Gomulki, przygotowane przez Jacka Głomba wg prozy Jerzego Pilcha (Teatr Lubuski, Zielona Góra), w Domu Kultury „Kolejarz”, przy ul. Andrzeja Struga 90 (obecnej siedzibie Teatru Szwalnia). Obok tak wybitnych w historii polskiej sceny spektakli jak przedstawienie

48 [Właściwie nazwisko naukowca miało postać - Termen, a rodowo - Theremin - przyp. red.] 
Jerzego Jarockiego (ze świetną scenografią stałego współpracownika Jarockiego - Jerzego Juka Kowarskiego i z plejadą gwiazd warszawskich, m.in.: Janusz Gajos, Jerzy Radziwiłowicz, Anna Seniuk, Jan Frycz, Barbara Horawianka, Mariusz Bonaszewski, Małgorzata Kożuchowska) czy też widowisko Krystiana Lupy (Maja Komorowska za rewelacyjną rolę Anny Meister otrzymała Tytuł Najlepszej Aktorki), których odegranie w Łodzi było prawdziwym świętem dla teatromanów, 14. Festiwal pokazal także cztery inne nowe polskie przedstawienia. Centrum Artystyczne Fabryka Trzciny we współpracy z Teatrem Nowym z warszawskiej Pragi w czasie swojej pierwszej - i bardzo udanej! - wizyty na Festiwalu zaprezentowało sztukę Elling Axela Hellsteniusa (reż. Michał Siegoczyński, ze świetnymi rolami Jarosława Boberka, Tomasza Karolaka i Tomasza Kota), która z pewnością była w tej edycji sztuką „najprzyjemniejszą”, a publiczność przyznała spektaklowi Tytuł Najlepszego Spektaklu (ex aequo z Miłościa na Krymie). Piotr Cieplak zaprezentował Watpliwość Johna Patricka Shanleya (Teatr Polonia, w rolach głównych Aleksandra Konieczna i Cezary Kosiński).

Wyjątkowym wydarzeniem na 14. Festiwalu była wizyta jego Gościa Honorowego - Danuty Szaflarskiej. Obecności w Łodzi znakomitej artystki towarzyszył szereg wydarzeń. Warszawski Teatr Narodowy zaprezentował w programie głównym Festiwalu spektakl Daily Soup Amanity Muskarii (czyli sióstr Gabrieli Muskały i Moniki Muskały, reż. Małgorzata Bogajewska), z Szaflarską w roli Babci. W Miejskiej Galerii Sztuki Willa otworzono wystawę autorstwa Przemysława Klonowskiego poświęconą Szaflarskiej. 9 marca odbył się „Dzień z Danutą Szaflarską", w którego ramach zaprezentowano przegląd filmów z udziałem aktorki, spotkanie z nią w Muzeum Kinematografii poprowadzila prof. Maria Kornatowska, a w Alei Gwiazd na ul. Piotrkowskiej odsłonięta została gwiazda artystki.

Gospodarze pokazali w przeglądzie swoją premierę sprzed roku: Imieniny Marka Modzelewskiego w reżyserii Sławińskiego. Przedstawienie wyróżniła Kapituła Loży Przyjaciół Teatru Powszechnego „[...] ze względu na podjęte przez Teatr Powszechny poszukiwania współczesnych tekstów, dających znakomite możliwości aktorom" ${ }^{49}$. Przy okazji tej inicjatywy Kapituły trzeba podkreślić ważną cechę Festiwalu. Otóż wraz z upływem lat miał on służyć już nie tylko wydźwignięciu Powszechnego z kłopotów repertuarowych, finansowych i wizerunkowych, nie tylko umożliwić łódzkiej publiczności obcowanie z wybitnymi spektaklami i świetną sztuką aktorską, ale także miał wywołać realną zmianę w polskim życiu teatralnym. Powinna ona polegać na ożywieniu nurtu komediowego $\mathrm{w}$ repertuarze polskich teatrów i odnowieniu gatunku komedii, a także podjęciu

49 Cyt. za: Maja Komorowska i Ivan Trojan najlepsi w Łodzi, strona internetowa radia RMF Classic, https://www.rmfclassic.pl/informacje/Slowo,11/Maja-Komorowska-iIvan-Trojan-najlepsi-w-Lodzi,11463.html (dostęp: 16.09.2016). 
dyskusji nad jej dzisiejszym stanem. Głównym działaniem zmierzającym w tym kierunku było powołanie przy Teatrze Powszechnym Polskiego Centrum Komedii, które ogłosiło konkurs na współczesną polską komedię - „Komediopisanie” (wśród jego jurorów zasiada najwybitniejsza polska znawczyni zagadnienia komedii prof. Dobrochna Ratajczakowa). Poczynania Centrum stały się elementem rozwijającym w praktyce idee Festiwalu i współdecydującym o jego kształcie ${ }^{50}$. Rozstrzygnięcie pierwszego konkursu odbyło się właśnie w czasie 14. Festiwalu, co miało podkreślać komplementarność działań obydwóch instytucji.

Na zakończenie Festiwalu, 17 marca - poza konkursem, to także utrwalająca się praktyka festiwalowa - odbył się mistrzowski pokaz Krystyny Jandy, która kreowała rolę „najgorszej śpiewaczki świata” - Florence Foster Jenkins w spektaklu Boska! Petera Quiltera (reż. Andrzej Domalik, Teatr Polonia).

Festiwal, coraz częściej identyfikowany z ważnym miejscem reprezentacji polskiej sceny, organizowal także istotne dla jej statusu wydarzenia, jak na przykład spotkanie poświęcone 50-leciu twórczości artystycznej jednego z najwybitniejszych polskich inscenizatorów - Jerzego Jarockiego. Długą rozmowę z prof. Jarockim poprowadził Tomasz Kulikowski, autor książki Reżyser. 50 lat twórczości Jerzego Jarockiego („mała litera”, ul. Traugutta 9).

Plakat do tej edycji Festiwalu przygotował Piotr Młodożeniec - grafik, rysownik, ilustrator, projektant, autor filmów animowanych, przedstawiciel słynnej plastycznej rodziny Młodożeńców (syn Jana i brat Stanisława). Na wyrafinowanym typograficznie plakacie widnieje - charakterystyczna dla twórczości artysty - postać uproszczonego ludzika (tym razem to postać podwojona i odwrócona jak sylwetki karciane, a także zróżnicowana pod względem wyobrażonej mimiki), która została wprowadzona w zabawną grę odwrotnościami kompozycji, barwy i gestu.

Kapituła Loży Przyjaciół Teatru Powszechnego podkreśliła wysoki poziom czternastej edycji festiwalu, potwierdzając odczucia publiczności. Łódzki przegląd stał się już nie tylko ważnym lokalnym wydarzeniem, dobrze rozpoznawalnym na teatralnej mapie Polski, ale zaczął powoli przejmować funkcję swego rodzaju wyznacznika poziomu rodzimej sceny - to tu spotykały się najlepsze spektakle mijającego sezonu. Sądzimy zatem, że dalsze referowanie festiwalowych przedstawień - najczęściej najwybitniejszych inscenizacji powstałych w ostatnich latach rozwoju polskiego teatru - byłoby i niewłaściwe, i niepotrzebne. Widowiska te są świetnie znane i wielokrotnie były opisywane przez krytyków i recenzentów teatralnych; nadal istnieją też w pamięci dzisiejszych widzów. A co z naszej perspektywy najważniejsze: ich wybór do repertuaru łódzkiego przeglądu nie był już - jak to się zdarzało we wcześniejszych latach - wynikiem eksperymentowania

50 Zob. Ewa Pilawska, Koncepcja programowa... 
ze strukturą wydarzenia, poszukiwania właściwej mu poetyki i drogi rozwoju. Po czterokrotnej reinterpretacji formuły Festiwalu, jego kształt ustabilizował się i osiągnął dojrzałość. Toteż w tej części naszej wypowiedzi chcielibyśmy skupić się na syntetycznym przeglądzie dorobku Festiwalu w latach $2009-2016^{51}$ i próbie podsumowania jego ewolucji.

Wedle przyjętej zasady, począwszy od 11 . Festiwalu (2005 r.), każdy z lódzkich przeglądów był profilowany zgodnie $\mathrm{z}$ hasłem danej edycji. Wokół problematyki wyznaczonej tematami Festiwali skupiały się towarzyszące im spotkania, w tym przede wszystkim - sukcesywnie rozbudowywane i z każdą edycją Festiwalu wypełniające się merytorycznie - dyskusje z udziałem specjalistów.

$\mathrm{W}$ mniejszym stopniu zorientowany na festiwalowe motta był sam repertuar przeglądu, który mial, jak podkreślaliśmy, przede wszystkim proponować doskonały zestaw nowych przedstawień, zaś ich ujęcie w wybranym aspekcie stawało się właśnie zadaniem aranżowanej w Teatrze Powszechnym krytycznej debaty i interpretacji festiwalowych haseł $\mathrm{w}$ toku wydarzeń towarzyszących.

Przyglądając się tematom kolejnych Festiwali - od jego piętnastej do dwudziestej drugiej edycji - można stwierdzić, iż większość z nich dotyczyła szeroko pojętej problematyki współczesnego teatru. I tak: w latach 2009 i 2010 podjęto temat „Estetyki współczesnego teatru”. Hasłem roku 2011 była „Rzeczywistość współczesnego teatru". W roku 2012 nadal interesowano się kwestią estetyki współczesnego teatru, ale poszerzoną o zagadnienie jego polityczności i zaangażowania, a w tym kontekście także - przyszłości (panel: „Przyszłość teatru”). Kolejnym przedmiotem namysłu festiwalowych dyskutantów była problematyka „Autorytetów, Ikon, Idoli” oraz ich konfrontacja „z dekonstruującymi teatralną rzeczywistość młodymi twórcami” (2013). Jubileuszowy 20. Festiwal przyjął temat „Mistrzowie” (2014), których reprezentował przede wszystkim współczesny Mistrz teatru - Krystian Lupa. W czasie Festiwalu podjęto także gorący temat Majdanu i - wraz z artystami z kijowskiego Teatru DAKH - rozważano problematykę narodzin niezależności i zobowiązań, jakie ten fakt nakłada na społeczność („Wojownicy i świadkowie”). Dwa kolejne przeglądy podejmowały refleksję nad „Kondycją współczesnego artysty” (sesje: „Konrad Swinarski. Kondycja artysty, którego nie ma” i „Tadeusz Kantor. Zderzenia”), a także próbowały odpowiedzieć na pytanie: „Czy współczesny artysta jest w kryzysie?” (2015). Rok 2016 poświęcony został w znacznym stopniu twórczości Krzysztofa Warlikowskiego (prezentacja Francuzów, projekcja Kruma i Alceste, wystawa Warlikowski. Przestrzenie humanizmu), co zaowocowało przeprowadzoną w międzynarodowym gronie dyskusją nad fenomenem sztuki artysty („Teatr, który szuka imienia”). Ale

51 [Artykuł obejmuje 22 edycje Festiwalu, tekst został ukończony jesienią 2016 roku - przyp. red.] 
kontynuowano także wątki kondycji współczesnego artysty („Artysta i jego ograniczenia”), poszerzając je o - stanowiące ważny temat namysłu współczesnych humanistów - zagadnienie funkcji ciała i cielesności we współczesnej kulturze („Ciało artysty”). Jak widać, z każdym rokiem rozbudowywana była refleksja krytyczna towarzysząca prezentacji spektakli, co stało się znaczącą cechą ewolucji Festiwalu. Warto podkreślić, że panele i sesje cieszyły się nie mniejszym zainteresowaniem publiczności niż same przedstawienia, co świadczy o utrwaleniu się także takiej tradycji rozmowy z widzami. Było to w znacznym stopniu zasługą grona dyskutantów, biorących udział w spotkaniach.

W sumie, w czasie ośmiu edycji Festiwalu w latach 2009-2016, Teatr przygotował aż dziesięć paneli dyskusyjnych, sesji i spotkań naukowych. Wśród zapraszanych do debat gości były wybitne w swoich dziedzinach autorytety, m.in.: ks. Adam Boniecki; artyści: Krystian Lupa, Nikołaj Kolada, Christian Longchamp, Vladislav Troitskyi, Natalia Worożbyt, Krystyna Janda, Dorota Kolak, Maciej Englert, Olgierd Łukaszewicz, Jacek Głomb, Jacek Poniedziałek, Michał Kmiecik; naukowcy i profesorowie: Patrice Pavis, Hans-Thies Lehmann, Georges Banu, Anna Kuligowska-Korzeniewska, Jan Ciechowicz, Andrzej Turowski, Małgorzata Leyko, Małgorzata Sugiera, Mateusz Borowski, Ryszard W. Kluszczyński, Jan Hartman, Przemysław Czapliński, Tomasz Majewski, Dorota Sajewska, Karolina Prykowska-Michalak; krytycy sztuki i animatorzy teatru: Renate Klett, Anda Rottenberg, Jarosław Suchan, Jaromir Jedliński, Jacek Sieradzki, Krzysztof Mieszkowski, Jacek Wakar, Joanna Derkaczew, Paweł Sztarbowski, Łukasz Drewniak, Agnieszka Lubomira Piotrowska, Dominika Łarionow; menadżer Sławomir Pietras. Panele dyskusyjne prowadzone były także przez krytyków teatralnych oraz publicystów, m.in. przez Katarzynę Janowską, Piotra Gruszczyńskiego i Jacka Żakowskiego.

W wyznaczane refleksją krytyczną ramy koncepcyjno-ideowe kolejnych Festiwali można było włożyć rozmaite przedstawienia, reprezentujące różnorodne tematy, a także odmienne formy i gatunki współczesnego teatru. Zawsze jednak musiał to być teatr na wysokim poziomie artystycznym i - już prawie bez wyjąt$\mathrm{ku}$ - prezentujący widowiska zupełnie nowe, zazwyczaj pochodzące z mijającego sezonu teatralnego.

Specyfiką programową Festiwalu było zatem niezmiennie sprowadzanie do Łodzi grona wybitnych twórców z ich najnowszymi produkcjami. Przedstawienia te prezentowane bywały także w ramach pokazów mistrzowskich i zawsze cieszyły się ogromnym zainteresowaniem publiczności, z entuzjazmem przyjmującej możliwość obejrzenia prawdziwych teatralnych bestsellerów ostatnich sezonów. Tak było już w czasie 15. Festiwalu (2009), kiedy w jego ramach zaprezentowane zostały m.in.: Kosmos Jarockiego, Anioty w Ameryce Warlikowskiego, Sprawa Dantona Klaty i Marat-Sade Tomaszuka, oraz podczas 16. Festiwalu (2010), gdy 
w Łodzi od lutego do kwietnia można było zobaczyć dziś już legendarne polskie spektakle: Wymazywanie Lupy, (A)polonię Warlikowskiego, Trylogię Klaty i Fedrę Kleczewskiej.

Wśród festiwalowych gości ostatnich lat z pewnością najważniejszą postacią byl - i jest - Krystian Lupa, który pokazał w omawianym okresie: Wymazywanie (2010), Poczekalnię.O (2014) i Wycinkę/Holzfällen (2015). Pamiętając, że wcześniej sprowadzone zostały z inicjatywy Teatru Powszechnego inne słynne przedstawienia artysty: Kalkwerk, Rodzeństwo, Niedokończony utwór na aktora oraz $\mathrm{Na}$ szczytach panuje cisza, trzeba podkreślić, że dzięki Festiwalowi łodzianie mieli nadzwyczajną możliwość bardzo dobrego poznania sztuki jednego z najważniejszych twórców współczesnego teatru ${ }^{52}$.

Imponująca jest także grupa - reprezentujących różne pokolenia - reżyserów polskiego teatru, obecnych na Festiwalu w latach 2009-2016. Trzeba tu przynajmniej wymienić tak wybitnych artystów jak: Krystyna Meissner (Biate małżeństwo, 2011; Hopla żyjemy!, 2013; Uwolnić karpia, 2014); Mikołaj Grabowski (Pan Tadeusz czyli Ostatni Zajazd na Litwie, 2012); Maciej Wojtyszko (Roszada, 2010 z Pawłem Aignerem; Dowód na istnienie drugiego, 2015); Janusz Zaorski (Danuta W., 2013); Janusz Wiśniewski (Szkoła żon, 2015); Juliusz Machulski (opowieść o Niccolò Machiavellim - Machia, 2015); Adam Orzechowski (Broniewski, 2015 - Najlepszy Spektakl; Najlepszy Aktor - Robert Ninkiewicz; Tango Łódź, 2016 - Najlepszy Spektakl, przedstawienie napisane specjalnie dla łódzkiego Teatru Powszechnego i bardzo mocno osadzone w klimacie Łodzi przemysłowej); Anna Augustynowicz (Migrena, 2011); Rudolf Zioło (Plaża, 2009); Piotr Cieplak (Utwór sentymentalny na czterech aktorów, 2009; Król umiera, czyli ceremonie, 2011; Anna Polony - Najlepsza Aktorka, za rolę Królowej Małgorzaty); Piotr Tomaszuk (Marat-Sade, 2009); Krzysztof Warlikowski (pierwsza wizyta artysty - z Krumem Hanocha Levina - zaplanowana została już na rok 2007, jednak ostatecznie spektakl, w postaci projekcji filmowej, widzowie Festiwalu zobaczyli dopiero w 2016 roku, a Warlikowski pojawił się po raz pierwszy w roku 2009 z Aniołami w Ameryce - Najlepszy Spektakl; następnie zaś w roku 2010 z (A)polonia, i z Francuzami w roku 2016; wówczas także jako projekcję filmową pokazano Alceste); Paweł Miśkiewicz (Kupieckie kontrakty, 2013 - reżyser zaproponował widzom aktywny udział w spektaklu, polegający na chodzeniu i deklamowaniu tekstów; przedstawienie odbyło się w Domu Towarzystwa Kredytowego przy Pomorskiej 21; Mars: Odyseja, 2014 - to widowisko umiejscowiono w opuszczonej

52 [W roku 2018 na Festiwalu Krystian Lupa zaprezentował także Proces, a w roku 2020 - Capri - wyspa uciekinierów, wcześniej, w roku 2010 w ramach I edycji festiwalu Nowa Klasyka Europy przedstawiono Końcówkę Samuela Becketta przygotowaną przez Lupę z Teatro de La Abadia w Madrycie - przyp. red.] 
sali Teatru 7.15 w Hotelu Grand przy ulicy Traugutta); Jacek Głomb (Marsz Polonia, 2012; Car Samozwaniec, 2016); Paweł Szkotak (Miarka za miarkę, 2016); Norbert Rakowski (Plotka, 2009); Iwona Kempa (Rozmowy poufne, 2009); Maja Kleczewska (Fedra, 2010; Babel, 2011; Podróż zimowa, 2013 - Najlepszy Spektakl); Jan Klata (Sprawa Dantona, 2009 - Najlepszy Aktor, Wiesław Cichy; także nagroda Kapituły Loży Teatru Powszechnego dla spektaklu; Trylogia, 2010; Utwór o matce i ojczyźnie, 2011 - Najlepszy Spektakl; Wróg ludu, 2016 - Najlepszy Aktor, Juliusz Chrząstowski za rolę doktora Stockmanna); Grzegorz Wiśniewski (Zmierzch Bogów, 2011), Marcin Liber (III Furie, 2012 - Najlepsza Aktorka, Joanna Gonschorek za rolę Danuty Mutter/Stefanii Mutter); Monika Strzępka (Niech żyje wojna!!!, 2011; Tęczowa Trybuna, 2012; Courtney Love, 2013; Bitwa warszawska 1920, 2014 - Najlepszy Spektakl); Michał Siegoczyński (2084, 2010); Paweł Wolak i Katarzyna Dworak (Droga śliska od traw. Jak to diabet wsia się przeszedt, 2015); Michał Zadara (Wizyta starszej pani, 2009; Chopin bez fortepianu, 2015; Lilla Weneda, 2016 - Najlepsza Aktorka, Barbara Wysocka za rolę tytułową); Adam Sajnuk (Konstelacje, 2014 - Najlepszy Aktor, Grzegorz Małecki); Wiktor Rubin (Caryca Katarzyna, 2014 - Najlepsza Aktorka, Marta Ścisłowicz); Michał Borczuch (Apokalipsa, 2016); i wreszcie najmłodsi w tym gronie: Weronika Szczawińska (Artyści prowincjonalni, 2013); Radosław Rychcik (Dziady, 2015); Waldemar Raźniak (Wassa Żeleznowa, 2010); Katarzyna Kalwat (Bóg mordu, 2011); Michał Kmiecik (\#Dziady, 2013).

Grupę reżyserów polskich wzbogacili w czasie ośmiu edycji Festiwalu także artyści zagraniczni, realizujący widowiska na polskich scenach. Wśród nich tak wybitni jak: René Pollesch (Jackson Pollesch, TR Warszawa, 2012); Ondrej Spišák, słowacki reżyser, który w warszawskim Teatrze na Woli przygotował inscenizację rewelacyjnego dramatu Nasza klasa Tadeusza Słobodzianka (2011, Najlepszy Spektakl); Claude Bardouil (projekt taneczny Nancy. Wywiad zrealizowany przez francuskiego choreografa we współpracy z Magdaleną Popławską - tytuł Najlepszej Aktorki - Nowy Teatr Warszawa, 2013 oraz Wyczerpani, Nowy Teatr, Warszawa, 2015); Kornél Mundruczó (Nietoperz, TR Warszawa, 2014).

O zasadności kwalifikacji „międzynarodowy” dopisanej do nazwy Festiwalu świadczyły jednak przede wszystkim przedstawienia przywożone z zagranicy. W latach 2009-2016 organizatorzy zaprosili dziewięć takich spektakli: Spowiedź $w$ Tanacu (reż. Andrei Şerban, Teatr Odeon, Bukareszt i Akademia Wędrowna Andrei Şerbana, Rumunia, 2009); U Pani Miłosierdzia (reż. Silvana Omerzu, Teatr Mladinsko, Ljubljana, Słowenia, 2010); Trzecia Generacja (reż. Yael Ronen, koprodukcja Teatru Habima z Tel Avivu, Izrael i berlińskiego Schaubühne, Niemcy, 2010); Opowieści lasku wiedeńskiego (reż. Gábor Zsámbéki, Teatr im. Józefa Katony, Budapeszt, Węgry, 2011). Wyjątkowo pod tym względem zapisała się 18. edycja Festiwalu w 2012 roku, kiedy to pokazano dwa wybitne 
przedstawienia słynnych europejskich twórców: Patrzę Ci w oczy, społeczny kontekście zaślepienia! w reżyserii René Pollescha, przywiezione przez berlińską Volksbühne, a także Iluzje, w inscenizacji Iwana Wyrypajewa (Teatr Praktika, Moskwa). W kolejnych latach Festiwal odwiedził z Podróżami Guliwera Narodowy Teatr z Sibiu w Rumunii (reż. Silviu Purcărete, 2013) oraz - wspomniany już - Teatr DAKH (Kijów, Ukraina) ze spektaklem - Buda dla psa. Widok $z$ góry. Widok $z$ dołu, przygotowanym jako światowa prapremiera specjalnie na MFSPiN (reż. Vladislav Troitskyi, 2014). Zamyka listę dziewiąte zagraniczne przedstawienie: Śmieszna ciemność (reż. Dušan David Pařizek, Burgtheater, Wiedeń, 2015). Słuszności decyzji umiędzynarodowienia Festiwalu wydawały się dowodzić nagrody przyznawane przez publiczność: tytuł Najlepszej Aktorki otrzymały: Ramona Dumitrean i Andrea Tokai (za rolę Iriny w spektaklu Spowiedź $w$ Tanacu), Catrin Striebeck, Stefanie Reinsperger, Dorothee Hartinger, Frida-Lovis Hamannza (za role w Śmiesznej ciemności); Najlepszym Aktorem wybrany został przez widzów Fabian Hinrichs (za rolę w Patrzę Ci w oczy, społeczny kontekście zaślepienia!) oraz Claude Bardouil (za rolę w Nancy. Wywiad). Natomiast Najlepszym Spektaklem zostały Iluzje Iwana Wyrypajewa.

Korzystając z obecności zagranicznych teatrów, wielokrotnie organizowano spotkania $\mathrm{z}$ ich twórcami, a także przygotowywano wydarzenia tematyczne poświęcone teatrom narodowym czy nowym polskim książkom dotyczącym rozwoju dramatu w wybranym kręgu kulturowym.

W ramach Festiwalu prezentowane były także znakomite przedstawienia przygotowane przez wybitnych polskich twórców na scenie Teatru Narodowego w Warszawie, na które łódzcy widzowie dojeżdżali specjalnie zorganizowanym transportem; były to: Kosmos wg Witolda Gombrowicza (w reż. Jerzego Jarockiego, 2009) czy Kordian Juliusza Słowackiego (w reż. Jana Englerta, 2016).

Osobną refleksję należałoby poświęcić aktorkom i aktorom, które/którzy swoim kunsztem scenicznym przesądzali o poziomie festiwalowych spektakli. Niestety, w tym miejscu musimy poprzestać na lakonicznym stwierdzeniu, że - tak samo jak w poprzednich latach - to właśnie sztuka aktorska była największym magnesem zapełniającym sale widowiskowe MFSPiN - po kres ich przestrzennych możliwości. Odwiedziła Festiwal (i to po wielokroć) czołówka polskich artystów, a także wielu świetnych twórców z zagranicy. To właśnie ich kreacje były niecierpliwie wyczekiwane, zapadały widzom w pamięć, były podziwiane i gorąco dyskutowane w kuluarach.

Trzeba podkreślić, że wraz z dojrzewaniem formuly i zasięgu Festiwalu rozszerzała się także oferta artystyczna kierowana do publiczności. Obejmowała ona coraz większą liczbę wydarzeń reprezentujących różne gatunki sztuki, co nadawało imprezie charakter interdyscyplinarny. I właśnie w latach 2009-2016 ta cecha MFSPiN wydaje się świadczyć o kolejnej ewolucji, a może raczej - intensyfikacji 
jego cech. Towarzyszące przedstawieniom i dyskusjom wystawy, koncerty muzyki (już nie wyłącznie teatralnej), przeglądy filmów, ale także zupełnie nowe działania podejmowane $\mathrm{w}$ obrębie różnych sztuk performatywnych, coraz śmielej interpretowały i poszerzały krąg refleksji wyznaczanej przez spektakle i rozmowy. Organizatorzy proponowali „, [...] mariaż sztuk, zachęcając tym samym, by tematy poruszane przez twórców w spektaklach, miały swoje rozwinięcie i kontynuacje w szerszej dyskusji, przenoszącej się również na inne aspekty sztuki" 53 . Taka postawa przystawała do oczekiwań znacznej części publiczności, znamionując jednocześnie przemiany sposobu uczestniczenia w kulturze współczesnej. Zatem, obok kontynuowania tradycyjnych już na Festiwalu wystaw plastycznych (fotografia, plakat, malarstwo, grafika, rzeźba), których tylko w omawianym okresie było ponad 20, tworzono także np. instalacje site-specific i multimedialne. Dyplomanci z Pracowni Scenografii i Kostiumu Ewy Bloom-Kwiatkowskiej (i pod jej czujnym okiem) wykreowali instalację artystyczną Barykada. Powstał także mural Jana Wasińskiego, odwołujący się do idei sztuk przyjemnych i nieprzyjemnych, odsłonięty na dwa dni przed oficjalnym otwarciem 21 . FSPiN (13 marca 2015) na budynku przy skrzyżowaniu ulic Kilińskiego i Północnej. Nadzwyczajnym wydarzeniem była także - wspomniana już - inauguracja nowej kurtyny Teatru Powszechnego.

Wśród wystaw przeważały projekty kuratorskie, włączające w obszar Festiwalu idee nowej muzeologii. Autorskie wystawy poświęcone były wybitnym postaciom polskiej sztuki (np. wystawy: Halina Mikołajska, kuratorzy: Magdalena Kulesza, Agnieszka Paszkowska, Krzysztof Kelm, połączona z promocją książki Joanny Krakowskiej: Mikołajska. Teatr i PRL, 2012; Mistrz-uczeń. Świerzy-Pagowski, kurator: Piotr Dąbrowski, 2014), ale także wybranym zjawiskom (np.: Metafizyka i rzeczywistość: zachód/wschód, lokalny/globalny, prymitywizm/nowoczesność, mistycyzm/materializm, kurator: Maciej Mraczek, 2012). Autorski charakter miały również moduły projekcji filmowych (np. prezentacje filmów Ottona Premingera i Emanuela Finkiela w Kinie Polonia, kurator: Tomasz Majewski, 2012).

Podejmowanie nowych inicjatyw nie oznaczało jednak, że rezygnowano $\mathrm{z}$ tradycyjnych działań artystycznych, w tym poświęcania poszczególnych Festiwali wybitnym postaciom polskiej sztuki. I tak w roku 2009 szeroko zaprezentowano twórczość Edwarda Kłosińskiego (wystawy, przegląd filmów, panel dyskusyjny prowadzony przez prof. Marię Kornatowską w Muzeum Kinematografii, odsłonięcie gwiazdy artysty w łódzkiej Alei Gwiazd). Niezmiennie zamawiano także na kolejne edycje MFSPiN plakaty festiwalowe u wybitnych artystów (m.in. Stanisława Fijałkowskiego, Michała Batorego, Sławomira Iwańskiego).

53 Ewa Pilawska, tekst programowy, wprowadzający w XVIII MFSPiN, 2012, cyt. za: strona internetowa Teatru Powszechnego, https://powszechny.pl/pl/idea-2/ (dostęp: 10.08.2016). 
Wzmacnianie partnerskiej współpracy MFSPiN z innymi lódzkimi instytucjami przynosiło też efekty w postaci aranżowania wydarzeń w różnych miejscach Łodzi, a tym samym czynienia z całego miasta otwartej przestrzeni sztuki (np.: wystawa Tu urodzit się film - zorganizowana w Galeria Opus wspólnie z Instytutem Teatralnym im. Zbigniewa Raszewskiego w Warszawie; wystawy organizowane w Ośrodku Propagandy Sztuki; w Miejskiej Galerii Sztuki Willa; w Galerii Chimera czy w Hotelu Andel's). Rosnący status tódzkiego festiwalu powodował też, że również stołeczne instytucje chętnie podejmowały z nim wspólpracę (np. wystawy: Mistrz-uczeń. Lupa-Warlikowski. Kilka obrazów z teatru Krystiana Lupy i Krzysztofa Warlikowskiego, 2014; Konrad Swinarski. Kondycja artysty, którego nie ma, 2015 - zrealizowane wspólnie z Instytutem Teatralnym im. Zbigniewa Raszewskiego w Warszawie).

Wreszcie nowe wydarzenia muzyczne towarzyszące Festiwalowi także wyróżniały się różnorodnością. Prezentowano w ich trakcie twórczość najwybitniejszych współczesnych polskich kompozytorów związanych z teatrem: na Małej Scenie Powszechnego można było np. podziwiać Michała Sławeckiego (kontratenor) i akompaniującą mu na fortepianie Joannę Wicherek podczas koncertu muzyki Pawła Mykietyna. A jednocześnie oferowano publiczności koncerty różnorodnych stylistycznie wykonawców (m.in.: Motion Trio, Stanisława Celińska, Royal String Quartet i Bartek Wąsik).

Festiwal jako wydarzenie przez długie tygodnie zawłaszczające czas, wyobraźnię, a przede wszystkim - emocje łodzian, doczekał się także znamion własnego "folkloru”: 15 marca 2014 roku, po spektaklu Nietoperz, na scenie Teatru Powszechnego pojawił się Andrzej Poniedzielski, a wraz z nim 35 artystek i artystów z najważniejszych łódzkich teatrów. Stworzony w ten sposób „chór grecki”, pod kierunkiem swojego koryfeusza (i autora tekstu piosenki), zaprezentował prapremierowe wykonanie dzieła pt. Kochaj tę mgłę, które zostało stworzone specjalnie na potrzeby Festiwalu - dla silniejszej integracji jego społeczności.

Podsumowując powyższą próbę zebrania wszystkich (dotychczasowych) edycji festiwalu, można dostrzec, że słowa twórczyni Festiwalu Ewy Pilawskiej - o potrzebie stałej dbałości o wysoki poziom każdej z jego odsłon, nie są okolicznościową konstatacją. Dwadzieścia dwa lata trwania przeglądu to ponad 150 przedstawień przywiezionych z całej teatralnej Polski (i nie tylko z niej!) oraz imponująca lista wielkich nazwisk: zarówno reżyserek/reżyserów, aktorek/aktorów, jak i autorek/autorów, scenografek/scenografów i graficzek/grafików, które/którzy współpracowali i współpracują z łódzką sceną. To także pełne sale widzów obydwu scen Powszechnego i wszystkich zaprzyjaźnionych z Teatrem ośrodków kulturalnych. To również dziesiątki osób zaangażowanych $\mathrm{w}$ pracę przy organizacji festiwalu. Teatr corocznie ogłasza nabór wolontariuszy i kieruje swoje zaproszenie przede wszystkim do uczniów i studentów. To dobra okazja, 
aby młodzi ludzie mogli zaznajomić się z funkcjonowaniem przeglądu „od kulis”, doświadczyć jego wyjątkowości i móc współtworzyć to wydarzenie.

Cieszy fakt, że Festiwal - pomimo wieku, który jako jego rówieśnicy uważamy za dojrzały - wciąż się rozwija, i wciąż poszukiwane są nowe możliwości przyciągnięcia do niego widzów, których z roku na rok przybywa. Czterokrotna zmiana festiwalowej konwencji i bardzo różnorodne wydarzenia towarzyszące przeglądowi zdają się sugerować, że w kolejnych latach możemy liczyć na jeszcze więcej atrakcyjnych artystycznie propozycji. Co więcej, rozwijająca się dynamicznie Łódź stwarza nowe, niemożliwe wcześniej do zrealizowania (lub przynajmniej mało możliwe) okoliczności i szanse udoskonalania Festiwalu. Mamy tu na myśli np. tworzenie nowych ośrodków kulturalnych (powstających w świetnie odnawianych poindustrialnych przestrzeniach), z którymi MFSPiN nawiązuje współpracę (jak choćby EC1), czy doskonalenie infrastruktury transportu (Łódzka Kolej Aglomeracyjna, Dworzec Łódź Fabryczna), dzięki którym możliwe byłoby „festiwalowe wędrowanie” z - i do - innych miast, a tym samym celebrowanie święta sztuki teatru w potężniejącej wspólnocie artystów i widzów.

Międzynarodowy Festiwal Sztuk Przyjemnych i Nieprzyjemnych stanowi także, jak sądzimy, dowód na wiarygodność przekonania, że naprawdę warto podejmować artystyczne ryzyko, które może zaowocować zjawiskiem trwałym i wartościowym. W tym wypadku - z próby ratowania podupadającego teatru - wyrosło jedno z największych i najważniejszych wydarzeń kulturalnych na mapie Polski.

Rówieśnicy Festiwalu - Paulina Chołys i Wojciech R. Pionko - najserdeczniej dziękują Pani Justynie Tomczak za nieocenioną pomoc w zdobyciu materialów do pracy.

\section{Bibliografia}

[Informacje potrzebne do powstania tego artykułu zostały zaczerpnięte $\mathrm{z}$ biuletynów, programów festiwalowych, strony internetowej Teatru Powszechnego w Łodzi, a także z publikacji teatrologicznych oraz z czasopism teatralnych i lokalnych, których niewielki wybór prezentujemy w bibliografii, adresy tekstów drukowanych w prasie codziennej znajdują się w przypisach] 
Gruszczyński Piotr, Czcij ojca swego, „Tygodnik Powszechny” 2001, nr 25.

Komorowski Jarosław, Dolino moja, Wachau, „Teatr” 1999, nr 2.

Pilawska Ewa, Koncepcja programowa Teatru Powszechnego w Łodzi [broszura], Łódź, maj 2015.

Sieradzki Jacek, Teatr ściętej głowy, „Polityka” 2000, nr 18.

Sztarbowski Pawel, Teatralny Tarantino, „Newsweek Polska” 2006, nr 46.

Węgrzyniak Rafał, „Magnetyzm serca” czyli „Śluby panieńskie”, „Odra” 1999, nr 10.

Zieliński Konrad, I w nieprzyjemnych przyjemność, dział Dobre Miasto Łódź, „Tygiel Kultury" 2006, nr 10-12.

\section{Netografia}

(dostęp: 10.08.2016)

http://teatrnowy.pl/

http://www.atlassztuki.pl/

http://www.e-teatr.pl

http://www.voovoo.pl

https://culture.pl/

https://powszechny.pl/

https://www.powszechny.com/ 